\title{
The Relationship Between TORT LAW AND INSURANCE IN ENGLAND AND WALES
}

Richard Lewis ${ }^{1}$

\section{The Influence of Insurance on the Tort System in General}

1 There is no doubt that insurance profoundly influences the practical operation of the law of tort. Liability insurance is not merely an ancillary device to protect the insured, but is the "primary medium for the payment of compensation, and tort law [is] a subsidiary part of the process." Although the majority of defendants in tort are individual people, they are almost all insured. In nine out of ten cases the real defendants are insurance companies, with the remainder comprising large self-insured organisations or public bodies. Only rarely are individuals the real defendants. Instead policyholders cede control over their case to their insurer and thereafter usually play little or no part in the litigation process. ${ }^{3}$ (Question 24) Insurers determine how the claim is to proceed and, for example, commonly make admissions without the consent of the insured, ${ }^{4}$ and settle cases in spite of the policyholder's objection. ${ }^{5}$

2 Insurers pay out 94 per cent of tort compensation. ${ }^{6}$ Classic studies reveal that it is their bureaucracy that dictates much litigation procedure, and determines when, and for how much, claims are settled. ${ }^{7}$ It is their buildings, rather than

1 Cardiff Law School, Cardiff University, PO Box 427, Cardiff CF10 3XJ, Wales, UK. E-Mail: LewisRK@cardiff.ac.uk. I am indebted to the members of the European Centre of Tort and Insurance Law (ECTIL) and to a number of insurance representatives for their contributions to a conference on this subject held in Munich in June 2004 at the offices of the reinsurers, Munich Re. I am also grateful for the comments of my colleagues Richard Moorhead and Antonia Layard, and to Harold Luntz, Malcom Clarke, and Chris Parsons.

2 P. Cane, Atiyah's Accidents, Compensation and the Law (6th edn. 1999), 191.

3 Harry Street admitted that he was once a defendant in a case but only discovered that it had been determined on appeal when he read about it in a newspaper! D.W. Elliott/H. Street, Road Accidents (1968), 209.

4 T. Goriely/R. Moorhead/P. Abrams, More Civil Justice? The Impact of the Woolf Reforms on Pre-Action Behaviour (2002), 90.

5 However, this very wide discretion given to insurers to conduct the litigation behind the insured's back is subject to some limit as recognised in Groom v Crocker [1939] 1 KB 194.

6 Report of the Royal Commission on Civil Liability and Compensation for Personal Injury (The Pearson Commission) (1978), Cmnd 7054, vol. 2 para. 509.

7 See H. Genn, Hard Bargaining (1987), D. Harris et al, Compensation for Illness and Injury (1984) and, in the USA context, H. L. Ross, Settled out of Court (1980). The major 
courts of law, or even solicitors' offices, ${ }^{8}$ that are the important centres of tort practice. The number of such centres has declined recently because of company mergers and greater specialisation which has concentrated the work in particular areas. Consolidation in the liability market ${ }^{9}$ has resulted in it being dominated by only eight major companies, although there are more than fifty other smaller firms issuing policies. All insurers have developed highly systematised approaches to claims handling, and make extensive use of information technology. They have increasingly structured their business, and closely monitor the performance of their claims handlers and lawyers. They have reduced the number of solicitors' firms that act for them. Their standard procedures have been further refined, especially for smaller claims and "fast track" cases. Economic pressures mean that communication between the parties takes place on the telephone rather than via letters or face to face meetings, and the outcome of a claim is likely to be influenced as much by a computerised assessment as by the discretion of the claims handler involved. ${ }^{10}$ Although these generalisations do not apply to all insurers in every type of case, ${ }^{11}$ they have a great effect upon the way in which tort rules are viewed and used in practice.

3 Because insurers dominate the system, it is very difficult to view any tort case in isolation: each and every case is affected, no matter whether determined in court or out of it. Insurers' control over the litigation process has not been emphasised sufficiently when the effect of insurance upon individual cases and on tort rules has been considered. However, it is dealt with immediately here in order to place in a wider institutional framework the cases used as examples later in this report.

4 Insurers are the paymasters of the tort system: they process the routine payments and they decide which elements of damage they will accept or contest.

findings are supported by the few, more recent, empirical studies and, in particular, by Goriely et al. (supra fn. 4). But see the critique of Genn, in: Dingwall et al., Firm Handling: The Litigation Strategies of Defence Lawyers in Personal Injury Cases, [2000] 20 Legal Studies, 1.

8 Lord Phillips, the Master of the Rolls, has even suggested that solicitors might no longer be involved with small claims where defendants are insured, and that insurers be left to administer these claims alone: Insurers should run small claims, [2004] Law Society Gazette, 29 April.

9 Office of Fair Trading, An Analysis of Current Problems in the UK Liability Insurance Market (OFT659a, 2003), para. 5.6. In 2002 although there were over 350 companies authorised to transact motor insurance, only 65 companies and 11 Lloyds syndicates actively did so. The ten largest motor insurers controlled two thirds of the market. $A B I R e$ sponse to the Greenaway Review of Compulsory Motor Insurance and Uninsured Driving (2004), annex B.

10 Goriely et al. (supra fn. 4), 31 and 149.

11 Dingwall et al. (supra fn. 7). 
It is unusual for them to contest liability ${ }^{12}$ and, as a result, they make at least some payment in 86 per cent of personal injury claims made against them. ${ }^{13}$ In the great majority of cases they pay not only compensation to claimants, but also the litigation costs of both sides. However, if an action fails the claimant may become liable for costs. To avoid this, loss insurers now offer claimants, after they have been injured, a policy which promises to pay their costs in the event of an unsuccessful claim. If the claim proves successful, the premium can even be added to the damages awarded in tort. Insurers may also offer legal expenses insurance in other contexts, ${ }^{14}$ and this can affect key aspects of the litigation. ${ }^{15}$ In particular, claimants cannot easily choose their own lawyer and may be required to use one from a panel approved by the insurer. ${ }^{16}$ The clients of these solicitors may receive a different service from those freely chosen by claimants, and conflicts of interest may arise. ${ }^{17}$ Insurers thus fund the tort system, control much of the representation, and can have an interest in whatever the outcome of a claim.

5 Insurers determine the extent that lawyers become involved in disputes, and the tactics that are used in the proceedings. Increasingly cases are being settled at an early stage, and without resort to the issue of court documents. ${ }^{18}$ Insurers decide, in particular, whether a case merits the very exceptional treat-

12 Goriely et al. (supra fn. 4), 103 found that insurers' files "contained remarkably little discussion of liability," finding it initially denied in only 20 per cent of cases.

13 Report of the Pearson Commission (supra fn. 6), vol. 2 para. 511. The relative importance to the tort system of road and industrial injuries for which insurers are most likely to be responsible has hardly changed since the Commission reported. Based on more recent data, Marshall and Morris suggest that 89 per cent of motor cases and 77 per cent of employers liability cases were successful in 2002-03. Resolving a Burning Fees Issue (2003) 23 Litigation Funding 12.

14 It is estimated that around 17 million motor policies and 15 million household policies offer "'Before the Event" Legal Expenses Insurance. Such insurers already control the litigation in 80 per cent of motor accident claims, and their market penetration is expected to continue to increase. P. Smith, Panel Solicitors: the Legal Expense Insurer's Perspective, [2004] 14 (3) PI Focus, 17.

15 P. Fenn/A. Gray/N. Rickman, The Impact of Sources of Finance on Personal Injury Litigation (2002) Lord Chancellor's Department No. 7/02. P. Abrams, In Safe Hands? Funding Litigation by Legal Expenses Insurance (2002).

$16 \mathrm{H}$. Blundell, Free to Choose? BTE Legal Expenses Insurance and Freedom of Choice, [2004] Journal of Personal Injury Law, 93. It is feared that all road accident litigation will be dealt with by no more than a hundred solicitors firms nationwide. S. Lawson, BTE Insurance - a Threat to the Profession or New Opportunities?, [2004] 14 (3) PI Focus, 17.

17 Abrams (supra fn. 15), chap. 8 and 9.

18 Goriely et al. (supra fn. 4), 159 found that almost all parties agreed that, after the Woolf reforms of civil procedure, cases were now more likely to be resolved without court involvement. Major insurers estimated that, because of earlier settlement, the number of cases disposed of only after the issue of formal proceedings had declined by a third. Even in the past, according to the Pearson Commission (supra fn. 6), vol. 2, table 12, 86 per cent of cases were settled without a writ being issued. 
ment of being taken to a court hearing. ${ }^{19}$ In effect, they allow trial judges to determine only one per cent of all the claims made. Only a few of these are appealed with the result that the senior judiciary are left to adjudicate upon a small fraction of what are, by then, very untypical cases. Whether an appeal court is to be given an opportunity to examine a point of tort law may depend upon the insurer for, if it serves the insurer's purpose for doubt to remain, the claimant can be paid in full and threatened with a costs award if the action is continued. ${ }^{20}$ In this sense tort principles themselves have been shaped by and for insurers, even though there has been a significant growth in the power of claimant lawyers in the last twenty years. ${ }^{21}$

6 Insurers' influence upon settlements is even more pronounced than it is upon decided cases. For the lawyer asked by his client to advise on the merits of a claim it is the realities of the litigation system that are of concern rather than the formal rules of law. Practitioners would agree with the key analysis of Ross $^{22}$ that the textbook rules of tort are often transformed when they come to be used in the system in three ways: firstly, they are simplified; secondly, they are made more liberal; and thirdly, they are made more inequitable. Simplification occurs because the rules are too uncertain when applied to the individual facts of particular accidents. For reasons of cost and administrative effi-

19 Before being set down for trial 98 per cent of cases are settled, and many more are concluded before any hearing takes place. The Pearson Commission (supra fn. 6), vol. 2, table 12. Similarly P. Pleasence, Personal Injury Litigation in Practice (1998), 12 reveals that only 5 out of the 762 "ordinary" cases with costs of less than $£ 5,000$ that were studied went to trial. Earlier, Harris et al. (supra fn. 7) had suggested that the figure might be as high as 3 per cent. However, even in cases involving very substantial awards of damages - $£ 150,000$ or more paid by insurers in 1987 and 1988 - only ten per cent of payments were the result of formal court orders, and most of these related to children or patients for whom court approval of their settlements is required. P. Cornes, Coping with Catastrophic Injury (1993), 20.

20 As recognised in Davis v Johnson [1979] AC 264 at 278. But see the failed attempt to prevent the House of Lords considering important causation issues in relation to asbestos liability in Fairchild v Glenhaven Funeral Services Ltd [2002] 1 AC 32 discussed by K. Oliphant in: H. Koziol/B.C. Steininger (eds), European Tort Law 2002 (2003), 148, and in [2002] 12 (3) Association of Personal Injury Lawyers Newsletter, 19.

21 Claimant lawyers are now much more likely to be specialists and work in larger and much better organised firms than in the past. Relying upon Law Society figures, Goriely et al. (supra fn. 4), note 4 at 25 note that even before April 2000 (when almost all legal aid was abolished for personal injury claims) solicitors were becoming increasingly specialised, and fewer firms were "dabbling" in such work. The founding of the Association of Personal Injury Lawyers in 1990 and its subsequent activity reflects the increasing abilities and resources of claimant lawyers. Melville-Williams, A. P. I. L., [1991] 19 Civil Justice Quarterly, 103. The Association now has over 5,200 members, employs 28 people, and has a turnover of $£ 1.95$ million. It is extremely well organised, and has its own Press, Parliamentary and Research officers as well as other administrators. See APIL, Annual Report and Accounts 2004.

22 H.L. Ross, Settled out of Court (1980). 
ciency, insurers have been forced to substitute other criteria for the strict tort rules. Mechanical rules of thumb - such as the car running into the back of another always being found the one at fault - replace any detailed investigation into blame. There is neither the time nor resources to instruct experts to analyse the scene of each road accident and precisely measure its effect upon the individual claimant. Cases are disposed of on the basis of paperwork alone, and this may bear only a limited relationship with what actually occurred. The result of the cost pressures upon insurers is that more claims succeed than the strict rules of tort would allow. Many insurers pay something for claims which, on full investigation, would be without foundation. As a result:

“... wherever there is insurance there is ... a closer approximation to the objectives of social insurance in fact than the doctrines of tort law would lead one to suppose." ${ }^{23}$

7 However, this liberality is but part of a system which overall is weighted in favour of insurers and results in much inequality. Indeed the case often used to illustrate the general inequalities in the legal system involves a "oneshotter" accident victim suing a "repeat player" insurer. ${ }^{24}$ Delay, uncertainty, financial need and other pressures cause claimants to accept sums much lower than a judge would award. The eagerness of claimants and their solicitors to get something from the system is reflected in the fact that they have been found to be very keen to accept any formal offer made to them by the "risk neutral" insurer. ${ }^{25}$ Those who can withstand the pressures of litigation do better than those who cannot, with the result that those from a particular class or background are more likely to succeed. ${ }^{26}$ Those who suffer most are the severely injured. Although in the greatest need, they will find their high value claim scrutinised in detail and processed very differently from the average case which typically involves but a minor upset and little, if any, financial loss. Those seriously injured are much less likely to receive "full" compensation than those suffering minor injuries who, for a variety of reasons, are likely to be over-compensated. ${ }^{27}$ The overall result of the settlement system is that

23 F.V. Harper/Fleming James, The Law of Torts (1956), s 13.7.

24 The seminal article is M. Galanter, Why the 'Haves' Come Out Ahead, [1974] 9 Law and Society Review, 95. However, Dingwall et al. (supra fn. 11) emphasise that not all defendants in personal injury cases are "repeat players" and they should not be treated as a homogenous group. Other limits of the article were examined in an anniversary special issue in [1999] 33 Law and Society Review, 795.

25 According to D. Harris et al. (supra fn. 19), table 3.3 claimants' solicitors used to accept the first formal offer made to them in two out of three cases. More recently Goriely et al. (supra fn. 4), 154 found more incidence of bargaining, although a third of cases still settled after only one offer, almost two thirds after two and ninety per cent after three.

26 Ross (supra fn. 22).

27 P.A. Bell/J. O'Connell, Accidental Justice: The Dilemmas of Tort Law (1997), 63-66. D. Dewees/D. Duff/M. Trebilcock, Exploring the Domain of Accident Law: Taking the Facts Seriously (1996), 19. 
rough and ready justice is dispensed, much influenced by insurance company personnel and procedures, and driven by the needs of the insurance industry. The system produces arbitrary results and bears only a limited relationship to the portrayal of justice contained in the traditional tort textbook.

8 The importance of insurers to the tort system is reflected in the fact that the claims which are brought closely match the areas where liability insurance is to be found. Thus road and work accidents predominate partly because they are the two major areas where tort insurance is compulsory. They constitute 86 per cent of all the claims brought for personal injury. ${ }^{28}$ They dominate the practice of tort even though they are relatively minor causes of disability and incapacity for work. ${ }^{29}$ Those suffering injury in areas not covered by insurance are extremely unlikely to obtain compensation. According to one study, whereas 1 in 4 road accident victims and 1 in 10 work accident victims gain compensation from tort, only 1 in 67 injured elsewhere do so. ${ }^{30}$

9 The scope of the tort system is affected not only by those areas where liability insurance has been made compulsory, but also by the existence of alternative sources of compensation. What opportunities are there for resort to either welfare payments from public insurance, or policy monies from first party private insurance? The interrelationship of compensation systems cannot be discussed in detail here, ${ }^{31}$ but a couple of examples will suffice to demonstrate the potential effects of other insurance systems upon tort. The first example is a historical one, and in practice resulted in the abandonment of tort law for the

28 Compensation Recovery Unit figures for 2003-04, with motor comprising 48 per cent of the total and employer liability 37 per cent. Similarly Datamonitor, UK Personal Injury Litigation 2003 fig 5. The nature of litigation in this respect has hardly changed for the Pearson Commission total figure of 88 per cent was only 2 per cent more than that reported twenty five years later. Op cit vol. 2 table 11. Atiyah suspected that the relative proportion of claims had not changed. P.S. Atiyah, The Damages Lottery (1997), 99.

29 Harris (supra fn. 19), table 2.1 found that the most common accidents were those in the home, or suffered in the course of leisure activities or in playing sport, and yet very few of these resulted in any damages award. Although work and transport injuries dominate the tort system they comprise only about half of all accidents according to Pearson (supra fn. 6), vol. 2, table 57. Datamonitor (supra fn. 28), 79 estimate that there were 7.8 million accidents in the home in 1999 of which only 0.5 per cent potentially could result in a successful tort claim.

30 The Pearson Commission (supra fn. 6), vol. 1, table 5. The study reveals that only 6.5 per cent of all accident victims incapacitated for three days of more are compensated by the tort system. However, if only serious injuries are considered tort becomes much more important. Where an accident causes incapacity for work for six months or more, almost a third of claimants receive tort damages. Harris et al (supra fn. 19) made similar findings concerning the limited importance of the tort system. Its significance is reduced tenfold if account is taken of those suffering disablement not from accidents alone but from all causes, including illness and disease.

31 For a recent example see U. Magnus (ed), The Impact of Social Security Law on Tort Law (2003). 
great majority of work injuries. It derives from the "election" rule whereby workers injured in the course of their employment had to choose either to sue in tort or to claim private insurance benefits on a no-fault basis from their employer. They could not obtain both damages in tort and these insurance benefits. For a variety of reasons employees overwhelmingly opted, or were pressed into receiving the no-fault benefits, ${ }^{32}$ leaving the tort system with a very limited role to play in the industrial field. ${ }^{33}$ Although this "employer privilege" continues in North America, a few European countries, and increasingly in Australia, it was abolished in the UK in 1948. Tort claims for work accidents have since flourished, and now constitute over a third of all the actions brought. ${ }^{34}$

10 A second example of the influence of insurance upon the extent to which resort is had to litigation involves private agreements between insurers to abandon the tort system in respect of certain losses. This may take various forms,${ }^{35}$ but the agreement which has come to public attention is the so called "knock for knock" arrangement in relation to motor accidents. Although more reluctant to do so in recent years, motor insurers have set up a series of agreements with other insurers which have similar risk profiles concerning the extent to which they will litigate. In advance of any accident involving claimants covered by both first and third party insurance, they agree firstly, that each will indemnify the property damage suffered by its own policyholder; and secondly, that they will not use the tort system to reclaim any of this loss from the other party even if they were clearly responsible for the damage. Where an insurer suffers a loss as a result of this arrangement, it hopes to make up for it in a later case. Overall, insurers expect that matters will even themselves out. These agreements are made in order to avoid the excessive cost and uncertainty that would be involved if insurers were forced to use the tort system for all small claims. They result from the inter-relationship of first party insurance with the tort system.

11 This influence of insurance upon the general pattern of tort liability is matched by its effect upon the level of compensation awarded. The principles upon which damages are assessed implicitly recognise that it is a company with a deep pocket that will pay and not an individual. Although most awards in tort are for very limited sums - little more than $£ 2,500^{36}$ - there are very

32 W.A. Dinsdale, History of Accident Insurance in Great Britain (1954), 161. For judicial criticism of the "deplorable" and "extremely shabby" tactics used by insurers see Deane v H. F. Edwards \& Co (1941) 34 BWCC 183.

33 P.W.J. Bartrip, Workmen's Compensation in Twentieth Century Britain (1987), chap. 10.

${ }^{34}$ Compensation Recovery Unit figures for 2003-4. Contrast the somewhat lower proportion cited by Datamonitor, UK Personal Injury Litigation 2003, fig 5.

${ }^{35}$ R. Lewis, Insurers' Agreements not to Enforce their Strict Legal Rights, [1985] 48 Modern Law Review, 275.

36 This is the median figure in the survey of 81,000 cases receiving legal aid and closed in 1996 - 97 in P. Pleasence, Personal Injury Litigation in Practice (1998), 40 fig 3.17. In 
few individuals who could afford to pay the amounts required in serious injury cases. The justice of the case never merits an investigation into the limited means of the average person found liable because that person will not have to pay. If it were not for insurance there would be little hope of restoring the claimant to the pre-accident position in a serious injury case. It is doubtful whether we would even wish to attempt to place full responsibility for the damage on most defendants. The very nature of the tort system would have to change. Without insurance, it is probable that tort liability itself could not survive. $^{37}$

12 These facts about the tort system have been empirically established in a series of studies, ${ }^{38}$ but gain little prominence in tort textbooks. ${ }^{39}$ (Question 8) In spite of students being left in ignorance, it cannot be denied that insurance in this context is fundamental to the general operation of the tort system. Over fifty years ago one writer concluded that the doctrines of tort law

"... are horse and buggy rules in an age of machinery; and they might well have gone to the scrap heap some time ago had not the tremendous growth of liability insurance and the progressive ingenuity of the compa-

70 per cent of successful cases the damages were less than $£ 5,000$, although the overall average was $£ 11,000$. P. Fenn/ N. Rickman, Costs of Low Value Liability Claims 19972002 , report average damages of only $£ 3,000$ for employers liability accident claims, although this study of almost 100,000 cases related only to claims for less than $£ 15,000$. See http://www.dca.gov.uk/majrep/claims/elclaims.htm . Datamonitor (supra fn. 28), 81 reports the average general liability personal injury claim in 2002 cost $£ 4,407$. In evidence to the Law Commission in 1993 the Trades Union Council noted that the average sum obtained in the 150,000 union-backed cases in 1991 was under $£ 2,000$.

37 J.G. Fleming, The American Tort Process (1988), 21. Without insurance, the system "would long ago have collapsed under the weight of the demands put on it and been replaced by an alternative, and perhaps more efficient system of accident compensation." J.G. Fleming, The Law of Torts (9th edn. 1998), 13.

38 Extensively referenced in Dewees et al. (supra fn. 27). But see Saks, Do We Really Know Anything about the Behaviour of the Tort Litigation System - and Why Not?, [1992] 140 University of Pennsylvania Law Review and American Law Register, 1147.

39 The major exception being P. Cane (supra fn. 2), especially chap. 9. There is little useful discussion in the many student and practitioner texts with the exception of M. Jones, Textbook on Torts (8th edn. 2002), s.1.3 and S. Deakin/A. Johnson/B. Markesinis, Tort Law (5th edn. 2003). J.G. Fleming, The Law of Torts (9th edn. 1998), 13 regards insurance as the cause of a vast expansion in liability and this "pervasive trend runs like a golden thread" throughout the book. There are few insurance textbooks compared to tort, but they similarly avoid examination of the effect of insurance on tort liability. A notable exception is the excellent section in M.A. Clarke, Policies and Perceptions of Insurance (1997), chap. 8 . 
nies made it possible to get some of the benefits of social insurance under - or perhaps in spite of - the legal rules." 40

13 Although insurance has had this profound effect upon the tort system, there remains much doubt about, firstly, whether the presence or absence of insurance in a particular claim has an effect upon liability in that case; and, secondly, the extent to which the rules of tort themselves have been revised to take account of the distributive effect of insurance. These are matters discussed in later sections of this report.

\section{The Areas Of Compulsory Insurance (Questions 2-4)}

14 In the UK the two most important areas where it is compulsory for there to be liability insurance are well known and not dealt with in detail here even though they provide the focus for much tort litigation. ${ }^{41}$ There must be insurance against liability incurred, firstly, by those using a motor vehicle in a public place; and secondly, by an employer for injury to his employees in the course of their employment. ${ }^{42}$ These two areas of liability are of vital importance to the tort system for, as stated above, they comprise almost 9 out of 10 claims made for personal injury. The incidence of tort liability thus closely mirrors the areas of compulsory insurance.

15 The other areas of compulsory insurance are relatively minor in respect of personal injury, but are significant with regard to protection against economic loss. (Question 2) However, these miscellaneous instances of compulsory insurance reveal a lack of coherent legislative policy with regard to the need for such protection, at least in relation to personal injury. It is difficult to discern why insurance should be required in respect of certain accidents but not others. The ad hoc introduction of compulsion into the occasional statute has taken place without discussion of the potential problems caused by the lack of cover in related areas. The anomalies that result can be illustrated by the fact that insurance is required for injury caused by horses and wild animals, but not for more common injuries caused by bicycles or dogs; it is required for cars and aircraft, but not for boats or trains; it is required of employers with regard to claims from their employees but not from members of the public;

40 J. Fleming, Accident Liability Reconsidered: The Impact of Liability Insurance, [1948] 57 Yale Law Journal (Yale L J) 549, at 569.

41 C. Parsons, Employers Liability Insurance - How Secure is the System?, [1999] 28 Industrial Law Journal, 109.

42 Road Traffic Act 1988 ss 143 and 145, and the Employers Liability (Compulsory Insurance) Act 1969 and the relevant regulations (SI 1998 No 2573). Since 1999 employers have been required to secure cover for up to $£ 5$ million in respect of any one occurrence, but in practice most insurers buy cover in the $£ 10$ to $£ 50$ million range. For a motor vehicle, as an alternative to insurance, by s 144 of the 1988 Act it is possible to deposit $£ 500,000$ with the Supreme Court. Some public bodies are also exempt from the requirement to insure. 
and it applies to nuclear reactors, but not to those using explosives or engaged in other activities which are exceptionally hazardous. Finally it is required for causing oil pollution at sea, but not for causing it on land. The full list is as follows:

Owners of horse riding establishments are required to insure against liability for injuries resulting from the hire or use of their horses. ${ }^{43}$

A keeper of a dangerous wild animal can only do so under licence, a condition of which is that there is insurance against liability for any damage caused by the animal. ${ }^{44}$

Aircraft operators are required to hold liability insurance as a condition of obtaining their licence. ${ }^{45}$

A licensee of a nuclear reactor is strictly liable for all damage caused and must carry liability insurance or make otherwise suitable provision for compensation claims. ${ }^{46}$

$\square$ Owners of ships carrying more than 2000 tons of oil and entering or leaving a UK port must be insured against liability ${ }^{47}$ The relevant legislation also makes provision for the implementation of an international convention ${ }^{48}$ which will extend the duty to insure to owners of all ships carrying any of 6000 defined substances, including oil and gas. When the provisions come into force the liability will be strict. ${ }^{49}$ The possibility of compulsory insurance for a broad range of environmental damage is also envisaged in a draft European Directive. ${ }^{50}$

43 Riding Establishments Act 1970 s. 1 (4A) (d).

44 Dangerous Wild Animals Act 1976 s 1(6) (iv).

45 Civil Aviation (Licensing) Act 1960 and the relevant regulations SI 1964 No 1116.

46 Nuclear Installations Act 1965 s 19.

47 Merchant Shipping Act 1995 s 163, and the Oil Pollution (Compulsory Insurance) Regs 1997 No 1820. In 2002 the UK also signed the International Convention on Civil Liability for Pollution Damage Caused by Bunker Oil adopted by the International Maritime Organisation (IMO) in 2001. The UK acted in support of the Convention's aims of ensuring all sources of marine pollution are covered by international strict liability and compulsory insurance regimes.

48 The Hazardous and Noxious Substances Convention adopted by the IMO in May 1996.

49 Little, [1998] Lloyds Maritime and Commercial Law Quaterly, 554.

50 Art. 14 para. 2 of the draft European Directive on Environmental Liability states that, after a review of the financial security provisions, proposals may be submitted for mandatory financial security. Compulsory insurance may then be required. 
Insurance may also be required for a ship in UK waters in respect of a wider range of liabilities than those relating to the environment as discussed above. ${ }^{51}$

Solicitors are required to insure against their professional liabilities. ${ }^{52}$ Although there is no legislation forcing accountants or barristers to insure, their professional associations require them to do so.

Because the National Health Service indemnifies them for their work in the public service, neither doctors nor dentists are required to insure in such circumstances. However, when working as independent contractors they are not protected by the NHS and, although required by their professional associations to insure, there is no statutory requirement for them to do so. Even though the Secretary of State for Health can require doctors and dentists to insure, ${ }^{53}$ this power has not been exercised. A Bill requiring these professionals to arrange an indemnity against liability failed to pass its Parliamentary stages in $2003 .{ }^{54}$ In contrast, certain other medical professionals are required by statute to insure. ${ }^{55}$

Independent financial advisers have been required to carry liability insurance by the industry regulator. ${ }^{56}$ Insurance intermediaries were formerly required to insure against liability ${ }^{57}$ and will shortly have a similar obligation when the Insurance Mediation Directive is implemented. ${ }^{58}$

Although legislation has been passed requiring estate agents to insure against liability for failing to account for clients' money, it has never been brought into force..$^{59}$

Related measures have been taken to protect the public against the insolvency of others having control over clients' money, but these have not always involved requiring insurance against tort liability as such. Bonds, insurance, or

51 Merchant Shipping Act 1995 s 192A, as inserted by s 16 of the Merchant Shipping And Maritime Security Act 1997.

52 Solicitors Act 1974 s 37, and the Solicitors Indemnity Insurance Rules 2002.

53 The Health Act 1999 s 9.

54 The Medical Practitioners and Dentists (Professional Negligence Insurance) Bill 2003.

55 For example, the Osteopaths Act 1993 and the Chiropractors Act 1994.

56 Financial Services and Markets Act 2000 s 138. Investment Firms: Proposed Policy and Rules (2003) at http://www.fsa.gov.uk/pubs/cp/cp193.pdf.

57 Under the Insurance Brokers (Registration) Act 1977 s 12.

58 For the proposed changes see FSA Consultation paper P193: Professional Indemnity Insurance for Personal Investment Firms: Proposed Policy and Rules (2003) at http://www.fsa.gov.uk/pubs/cp/cp193.pdf.

59 Estate Agents Act 1979 s 16. 
industry levies as security against insolvency, rather than liability, may be required, for example, of banks ${ }^{60}$ and travel agents. ${ }^{61}$

\section{A. Voluntary insurance}

16 Although, as discussed below, some do not insure in spite of being required by law to do so, it is also the case that many take out liability insurance even though they do not have to do so. For example, businesses usually carry public liability insurance to complement and extend their compulsory employers' coverage by including such risks as liability arising from their occupation of property. They may also voluntarily insure against specific risks that are usually excluded from general liability policies (such as those deriving from liability as manufacturers of products, or from liability arising from environmental and pollution control regulations). In addition, directors and officers' liability insurance may be purchased as a protection against managerial incompetence.

17 Ordinary individuals similarly will agree to take out liability insurance beyond the scope of the compulsory cover. Often they will be unaware of the extent to which they are protected because the purchase of liability insurance is not the main purpose of the transaction. For example, certain liabilities can be indemnified merely as a consequence of a policy taken out in order to obtain a mortgage on property or to protect payment for a holiday. Purchasers may be surprised to discover that they are protected against their liability for injuries on their property or resulting from their negligence on holiday. Again, those taking out loss insurance against the contents of their home being damaged may find, on reading their policy, that they are also covered for their liability to others in many circumstances. However, there are no statutes which force people to take out these different forms of liability insurance.

18 It is impossible to estimate the percentage of the population protected as potential claimants by liability insurance. (Question 4) It varies according to the cause of the injury and the type of loss suffered. In any event it must be remembered that strictly it is the defendant that is protected by such insurance; the claimant can only gain access to the compensation fund if liability can be established. Unlike in many other European countries at least with regard to motor vehicles, ${ }^{62}$ liability in the UK still requires proof of fault. As a result, as we have already seen, only a small minority of those injured by accident or disease obtain compensation even in areas where liability insurance is compulsory.

60 Banking Act 1979.

61 The Package Travel, Package Holidays and Package Tours Regulations 1992 (SI No 3288).

62 See B.A. Koch/H. Koziol (eds), Compensation for Personal Injury in a Comparative Perspective (2003) 


\section{B. Failure To Arrange The Insurance Required By Statute}

19 Failure to comply with the obligation to insure is subject to sanctions in the criminal law, the normal penalty being a small fine. ${ }^{63}$ (Question 3 ) The extent to which there is compliance varies. Although proof of insurance may be a pre-requisite to obtaining the relevant licence, there may still be many who avoid payment. It has been estimated that about 1 in 20 motorists, ${ }^{64}$ and about 1 in 200 employers $^{65}$ do not have the insurance required.

20 In the areas where insurance has been made compulsory further measures have been taken to ensure that compensation will be available despite the misdeeds or failings of a defendant. However, again here there are various anomalies in the protection given with the result that those injured on the road have more security than those injured at work or elsewhere. ${ }^{66}$ The state has intervened to regulate the tort system either directly by legislation, or indirectly by forcing insurers to ensure that the claims of certain accident victims will be met. Thus reserve funds levied from insurers will compensate, via the Motor Insurers' Bureau, if a motorist fails to comply with the obligation to insure. If the motorist is in breach of the terms of the insurance because, for example, he drove when drunk, or on business instead of pleasure, insurers are prevented from avoiding the policy with regard to the liabilities for which the driver must insure. There is similar, although less extensive, protection for an employee in a claim against an employer found to be in breach of a condition in his insurance policy. However, if an employer fails to comply with the statutory duty to insure there are no reserve funds available. The injured employee's claim may then be worthless. Finally, there is some protection for the

63 New fixed penalties were announced in June 2003, but for a first offence the motoring fine still averages only $£ 200$. There were 267,000 convictions for such a failure to insure in 2001, and in over half of the cases the fine was less than $£ 100$ according to the Home Office, Offences Relating to Motor Vehicles in England and Wales 2001 (2003). Employers can be fined up to $£ 2,500$ a day, but in practice the fines are low and enforcement more limited.

64 D. Greenaway, Uninsured Driving in the United Kingdom (2004), Department of Transport,London

http://www.dft.gov.uk/stellent/groups/dft_rdsafety/documents/page/dft_rdsafety_030393 .hcsp. Similar figures published by the Motor Insurers Information Centre show that there are over a million uninsured drivers are on the UK roads every day. http://www.miic.org.uk. The 5\% default rate in the UK is similar to that in Spain, and is better than those estimated for Italy and Greece, but it is much worse than that in Germany $(0.1 \%)$ and the Netherlands (1\%-2\%) according to the Association of British Insurers, Uninsured Driving in Europe (2004).

65 Department of Work and Pensions, Review of Employers' Liability Compulsory Insurance: Second Stage Report (2003). Contrast the Small Business Service telephone survey of over 2000 businesses in 2002 which suggested that the figure was 1 in 14 .

66 Parsons (supra fn. 41). 
claimant if the tortfeasor has gone bankrupt or into liquidation. ${ }^{67} \mathrm{~A}$ direct action against the insurer may then be allowed.

21 The effect of failure to comply with the obligation to insure in the civil law differs according to whether motor or employer's liability is being considered. In motor insurance, the failure gives rise to an action for breach of statutory duty against the person who should have taken out a policy. ${ }^{68}$ However, the practical effect of this is limited because the reserve funds will compensate in any event for injuries caused by an uninsured driver. In contrast, where the failure to insure is that of an employer rather than a motorist there are no reserve funds. A civil action for breach of statutory duty then could have practical value. However, the Court of Appeal has held that no such action can succeed with the result that a claimant was left without compensation when he sought damages personally from the directors of the uninsured and insolvent firm that had employed him. ${ }^{69}$ (Question 16)

\section{Failure To Arrange Insurance Other Than That Required By Statute (Questions 14-17)}

22 In general, although it is compulsory to insure in the areas listed above, there is no liability in English law for otherwise failing to take out insurance. Liability is usually established by proving fault, and it is not negligent if the only failure is to put in place measures to pay for losses tortiously caused. This can be illustrated by the position of parents and liability for their children. In the UK, although generally not liable for their children's torts, in theory parents could be liable for their own torts in failing to control their child. ${ }^{70}$ However, no parent has ever been found liable for failing to take out insurance either against their own liability, or against that of their child. (Question 15).

23 However, this principle that there is no general duty to insure has recently been qualified at least in relation to the liability of occupiers employing independent contractors on their property. Statute prescribes that, in order to avoid liability for the acts of a contractor, the occupier must take steps to ensure that the contractor is competent to do the work in question. At least where the contractor is doing hazardous work, a majority of the Court of Appeal has agreed that the occupier should inquire whether the contractor is covered by a liability insurance policy because this is one of the factors which is relevant in

67 Third Party (Rights Against Insurers) Act 1930. The deficiencies of this Act were noted by the Law Commission, Third Parties - Rights against Insurers Report No 272 (2001). See also the European Communities (Rights against Insurers) Regulations 2002 (SI No 3061) made pursuant to the Fourth Motor Insurance Directive (No 2000/26/EC).

68 Monk $v$ Warbey [1935] 1 KB 75.

69 Richardson v Pitt-Stanley [1995] 1 QB 123. However, this case was not followed in Scotland in Quinn v McGinty [1998] Rep LR 107.

70 See K. Oliphant, Children and the Law of Tort in England and Wales, in: ECTIL paper forthcoming. 
proving competence. However, this duty to make inquiries does not extend to checking the terms of the policy itself or to discovering whether the policy is still current. As a result, on the facts of the case, the occupier was held not liable for a negligent fairground contractor who had recently allowed his liability insurance policy to expire. ${ }^{71}$ Nor was a duty to check for insurance found where the contractor had already been approved by the local authority to carry out the task in question. ${ }^{72}$

24 If a defendant fails to take out not liability insurance, but first party insurance which would have indemnified the claimant against loss, again there is little authority in tort to support a claim. There can be contractual responsibilities which, for example, may require one party to insure for the benefit of others having an interest in the property in question. ${ }^{73}$ However, outside of contract or trust, there is no duty to insure. This general principle was affirmed in the case of a school that was held not liable for failing to take out insurance for the possibility of its children being injured in the course of playing sport. ${ }^{74}$ The court pointed out that there was no duty for the parent to insure the child and that it would therefore be inappropriate to place a more onerous duty upon the school. Again, in a related case, an employer was held not liable for failing to insure an employee against the risk of him being injured in the course of his employment by the fault of a third party who could not pay any damages himself. ${ }^{75}$ In this case the injury was suffered as a result of a road accident in Ethiopia. Although it is compulsory to insure against liability for injuries occurring in the UK, this does not extend to cover injury suffered abroad or where no liability can be established. There is therefore no duty to arrange first party insurance for another person.

25 Just as there is no common law principle requiring defendants to take out loss or liability insurance, there is no formal rule to support a claimant being found contributory negligent merely because he failed to take out first-party insurance. (Question 17) Thus a landlord who failed to insure his property was nevertheless able to succeed in his tort action against a tenant who negligently caused damage to that property. ${ }^{76}$ (Question 23) Similarly, the fact that a claimant has taken out first party insurance in a personal injury case is gener-

71 Gwilliam v West Hertfordshire NHS Trust [2003] QB 443. Even in this case one judge, Sedley LJ, strongly dissented from the view that there should be a duty to check for insurance. In Bottomley v Todmorden Cricket Club [2003] PIQR P18 although Sedley's dissent was supported by the first instance judge, on appeal, further support was given to the idea that insurance was relevant to establishing the competence of the contractor.

72 T Naylor v Payling [2004] EWCA 560.

73 As illustrated recently in Scottish \& Newcastle Plc v GD Construction (St Albans) Ltd [2003] EWCA Civ 16 and Oxford Aviation Services Ltd v Godolphin Management Co Ltd [2004] EWHC 232.

74 Van Oppen v Bedford Charity Trustees [1989] 3 All ER 389.

75 Rush v Reid \& Tompkins Group [1989] 3 All ER 228.

76 Lambert $v$ Keymood Ltd [1999] Lloyds Rep IR 80. 
ally ignored, and damages must be paid even though the loss has been compensated from this other source. ${ }^{77}$ Formally, the claimant is thus neither penalised for his prudence in arranging insurance, nor for his thoughtlessness in failing to insure.

\section{The Influence Of Insurance Upon Particular Cases And Rules: General Views}

26 In the opening section of this report we concluded that insurers have had a major effect upon the general operation of the tort system. However, there is much more doubt about the extent that insurance can be shown to be a factor taken into account to determine the outcome of individual cases. To what extent have facts been interpreted to fit the established basis for liability, and the result thus manufactured perhaps for the benefit of an uninsured claimant? More significant for the academic tort lawyer is the suggestion that, rather than the facts, it may be that the rules themselves that have been changed to accommodate the insurance position.

27 Why might this be done? We need not examine the economic, political and social arguments in detail here. However, in simple terms, some have argued that liability may more readily be imposed if the tort action is seen only as a means of compensating needy individuals, and the defendant is merely a conduit to an insurance fund and a means of distributing the cost of the injury to a wider pool. Conversely, if the claimant has his own insurance for the loss caused, his needs are less and liability may then be denied. "Who is insured?" and "who is in the better position to insure?" have thus been seen by some as key questions in determining liability issues. Whether it is economically more efficient for a loss to be met from first party insurance rather than from liability insurance via a tort claim raises wide issues. However, it is sufficient here to note that the relative insurability of the parties has been argued to be relevant when determining whether liability should be imposed.

\section{A. Judicial views}

28 In the past it was almost unknown for judges to examine or even acknowledge the existence of insurance relating to a claim, and it remains extremely unusual for them to do so. They have occasionally asserted that insurance has had no direct effect upon them, stating that it "is not the function of a court of law to fasten on the fortuitous circumstance of insurance to impose a greater burden" on the defendant than would otherwise be the case. ${ }^{78}$ However, their

77 R. Lewis, Deducting Benefits from Damages for Personal Injury (1999), chap. 6. However, in a property damage case insurance may have some effect. See, for example, Lamb v Camden LBC [1981] QB 625 discussed below.

78 Viscount Simonds in: Davie v New Merton Board Mills [1959] AC 604 at 627. Similar comments were made by the same judge in Lister v Romford Ice Storage Co Ltd [1957] AC 555 at 576, and by Lord Bridge in Hunt v Severs [1994] 2 AC 350 at 393. Lord Wil- 
general silence about such matters has not prevented speculation about whether the wider arguments relating to insurability are having an unacknowledged effect. It is difficult for judges to discuss insurance factors openly because they give rise to wide ranging policy considerations. In addition, if insurance were openly recognised as a determining factor, judges could be accused of deciding cases on the basis of the parties' means alone, and the idea that a rich or protected litigant must always lose to a poor or needy one is too simplistic to contemplate.

29 As an exception to the general rule, one judge, Lord Denning, was more prepared to examine the insurance background to disputes but even he did so only occasionally. Most famously, in a case over thirty years ago involving a learner driver being sued by her instructor for negligent driving, he suggested that the presence of liability insurance could determine the standard of care to be applied. He thought that the skill of a fully qualified driver could be required from the learner driver partly because she carried liability insurance.

"Parliament requires every driver to be insured against third party risks. The reason is so that a person injured by a motor car should not be left to bear the loss on his own, but should be compensated out of the insurance fund. The fund is better able to bear it than he can. But the injured person is only able to recover if the driver is liable in law. So the judges see to it that he is liable, unless he can prove care and skill of a high standard .... Thus we are ... moving away from the concept: 'No liability without fault.' We are beginning to apply the test: 'On whom should the risk fall?' Morally the learner driver is not at fault; but legally she is liable to be because she is insured and the risk should fall on her."79

30 Two years later he returned to the theme, pointing out that it was damages as well as liability that had been influenced:

"The damages are expected to be borne by the insurers. The courts themselves recognise this every day. They would not find negligence so readily - or award sums of such increasing magnitude - except on the footing that the damages are to be borne, not by the man himself, but by an insurance company." 80

31 Although the law reports contain no other statements as explicit as these, in the last fifteen years or so they have made increasing reference to insurance.

berforce in Morgans v Launchbury [1973] AC 127 at 137 thought it dangerous and irresponsible for a judge to alter the basis of liability without knowledge about the impact upon the insurance system.

79 Nettleship v Weston [1971] 2 QB 691 at 699.

80 Morris v Ford Motor Co Ltd [1973] QB 792 at 798 
Judges are more prepared than in the past to discuss wider policy issues, ${ }^{81}$ and these have sometimes included insurance aspects. ${ }^{82}$ Within this broader framework judges have referred to distributive justice whereby account is taken of the effects of a decision beyond the immediate parties to the dispute. In a recent lecture Lord Steyn stated:

"The primary aim of tort law is the pursuit of corrective justice. It requires somebody who has harmed another without justification to indemnify the other. There is, however, another perspective, namely considerations of distributive justice. It concentrates on the place of the plaintiff and the defendant in society.... Not surprisingly, our courts have not shut their eyes to such considerations: the insurance position of the parties has sometimes been treated as relevant." 83

32 Insurance, therefore, may be taken into account but only occasionally. It is difficult to forecast when and with what effect. There is considerable uncertainty.

\section{B. Commentators'views}

33 A Realist perspective upon the judicial role emphasises the importance of underlying policy considerations as against the formalist reasoning contained in the judgements themselves. Traditional judicial silence on insurance has provided a vacuum which a few tort scholars have sought to fill. Some have drawn inferences about the influence of insurance in spite the reasons expressly given in the judgements, whereas others have rejected such causal connections. There has been a sharp division in views. On the one hand, there are those who argue that the "hidden hand" of insurance has had a great effect; ${ }^{84}$ courts are said frequently "to treat tort as a compensation and loss-spreading scheme, via the pervasive phenomenon of liability insurance." ${ }^{5}$ Judges may

81 K. Malleson, The New Judiciary (1999), R. Stevens, The English Judges: Their Role in the Changing Constitution (2002), M. Kirby, Judicial Activism (2004).

82 For an Australian context see M. Gill, The Expansion of Liability and the Role of Insurance - Who's the Chicken?, [1999] International Journal of Insurance Law, 27.

83 Lord Steyn, Perspectives of Corrective and Distributive Justice in Tort Law, [2002] 23 Irish Jurist, 1. Similarly, in McFarlane v Tayside Health Board [2000] 2 AC 59 at 83 he described the duty of care as "a mosaic in which the principles of corrective and distributive justice are interwoven.” Lord Hoffmann said that corrective justice “... has been abandoned in favour of a cautious pragmatism" in Frost $v$ Chief Constable of South Yorkshire Police [1999] 2 AC 455 at 502.

84 J.G. Fleming, The Law of Torts (9th edn. 1998), 13 : "[W]hile in theory insurance follows liability, in experience insurance often paves the way to liability. In short it is the hidden persuader." It plays its role "from a hidden position behind the scenery" according to H. Cousy, Tort Liability and Liability Insurance: A Difficult Relationship, in: H. Koziol/B.C. Steininger (eds), European Tort Law 2001 (2002).

85 J. Morgan, Tort, Insurance and Incoherence, [2004] 67 Modern L Rev, 384 at 392. 
even be influenced without knowing it because insurance "acts as a stimulus to decision-making whether or not the decision-maker is consciously aware of it." 86 The result, according to Cane, is that "there can be little doubt that the development of the law has been influenced by the growing prevalence of liability insurance." 87 Another textbook agrees:

“... [T] practices, the notions of "duty" (and causation) are at times used to conceal insurance dictates and the term "negligence" is employed in contexts where the defendant could not humanly have avoided the accident in question." 88

Even if the rules themselves have not directly been affected, insurance may thus "invisibly" influence the result in a particular case. ${ }^{89}$

34 On the other hand, others have argued that the effect of insurance has been exaggerated and that in fact it has had little effect on tort rules themselves. Prosser's view, over thirty years ago, was that:

"While liability insurance undoubtedly has had an effect, it is difficult to escape the impression that all this has been very much overstated. A dispassionate observer, if such a one is to be found in this area, might ... conclude that the 'impact' of insurance upon the law of torts has been amazingly slight; that most of the changes that have been pointed out are due to other causes...."90

Similarly, Clarke argues that influence - in the sense that the law has been tailored to fit the insurance position - is scarcely to be seen at all. ${ }^{91}$

35 In examining these issues Stapleton has written a key article..$^{92}$ She argues that any causal link between the development of insurance and the expansion of tort liability must be viewed with caution. Echoing the words of Prosser, she concludes that when courts refer to insurance they do so only as a "make-

86 M. Davies, The End of the Affair: Duty of Care and Liability Insurance, [1989] 9 Legal Studies, 67 cf B. Cardozo, The Nature of the Judicial Process (1921), 12: "It is often through these subconscious forces that judges are kept consistent with themselves, and inconsistent with one another."

87 (Supra fn. 2), 203.

88 S. Deakin/A. Johnson/B. Markesinis, Tort Law (5th edn. 2003), 3.

89 J. Fleming, Accident Liability Reconsidered: The Impact of Liability Insurance, [1948] 57 Yale L J, 549 at 551.

90 W.L. Prosser, Law of Torts (4th edn. 1971), 547. In his evaluation of Prosser, White argues that, although insurance was not the primary factor, it did stimulate the growth of strict liability. G.E. White, Tort Law in America (1980), 172.

91 M.A. Clarke (supra fn. 39), 283.

92 Stapleton, Tort, Insurance and Ideology, [1995] 58 Modern Law Review, 820 
weight" factor after it has been decided to impose liability for other reasons. She points to tort rules which appear to be entirely unaffected by insurance factors, and argues that commentators have used the argument selectively to explain certain developments while ignoring other areas. There has been no fundamental shift in the formal basis of tort law such as might have been expected if insurance were to provide a new foundation for its development. The formal rules still usually require proof of fault, and the failure to move decisively towards a stricter liability is evidence of the limited effect of insurance. Finally, Stapleton is concerned that if attention is paid only to insurability, the potential deterrent or corrective role of tort will be suppressed. Even though many will not share the belief that, in practice, tort has much effect in controlling behaviour or achieving deterrence, and many may doubt that the tort system produces results which have such high claims to justice, nevertheless they will agree that it is a mistake to place too much emphasis upon tort law as a means of compensation. Tort is but one of a number of compensation options available, or which might be developed. ${ }^{93}$

36 In spite of these criticisms Stapleton acknowledges that insurance is clearly relevant to "the operation of tort law in daily life." This includes its effect upon who sues, and the dynamics of the settlement process. In addition, she agrees that judges are fully aware that it is the insurer who pays, and, at a very general level, it is likely that courts have been influenced. However, she casts doubt upon more specific claims that link the expansion of tort liability with the availability of liability insurance.

37 Although there is much to agree with here, ${ }^{94}$ it is not always easy in practice to draw the distinctions upon which the analysis relies. In particular, it can be difficult to isolate individual decision making from the institutional framework of the tort system. Stapleton accepts, but does not expand upon, the influence of insurance on the "operation of tort law in daily life." This was outlined at the beginning of this report where it was suggested that insurers' control and administration of the tort system affects all claims. In particular, later in this report it is argued that the pervasive influence of insurance becomes clearer if the focus changes from liability to the assessment of damages. Re-

93 S. Sugarman, Personal Injury and Social Policy - Institutional and Ideological Alternatives, in: N. Mullany/A.M. Linden (eds.), Torts Tomorrow (1998). One such alternative was given in S. Sugarman, Doing away with Personal Injury Law (1989), and another in T. Ison, Compensation Systems for Injury and Disease: The Policy Choices (1994). These solutions can be contrasted with, for example, the first party insurance proposals of P.S. Atiyah, The Damages Lottery (1997), and the reform suggestions noted by Dewees et al. (supra fn. 27).

94 In criticising the article, Morgan, [2004] 67 Modern Law Review, 384 does not reflect upon the subtleties in Stapleton's argument contained in the previous paragraph, and rather than engaging with the detailed analysis of the caselaw she presents, relies upon only two recent cases to substantiate his argument that courts "frequently" take insurance into account. Unfortunately, this is the very generalisation to which Stapleton objects. 
storing the victim to his pre-accident position becomes inconceivable in serious injury cases in the absence of a mechanism for distributing the cost of doing so. In this sense each award of substantial damages reflects the importance of insurance to the tort system. Finally, even if we accept that tort rules themselves have not been changed substantially by insurance we might still conclude that, in determining the facts of a particular case, judges have been "invisibly" affected by knowledge of the insurance position. The "sympathetic factor" at trial is known to litigators, and is what Clarke calls the "magnetic effect" of money whereby the result is influenced by any deep pocket in a case. ${ }^{95}$ Fitting the facts, rather than the law, to the insurance position limits the value of Stapleton's analysis.

\section{Conclusion}

38 All commentators therefore agree that insurance undoubtedly has had some influence upon tort; it is only the extent of this influence that is open to question. Here it is argued that that influence has been substantial. Not only has insurance had a profound effect upon the operation of the claims system in general, but it has also influenced individual cases. Practitioners are aware that insurance is one of the factors that may determine the inferences to be drawn from the facts of the case. It competes with the moral basis of the fault principle in this regard. Sometimes the insurance factor and the need for compensation will triumph, and negligence will be found where none existed; but occasionally the absence of fault will prevent the claim from succeeding. The morality of the fault principle still has a great effect upon determining liability, but the general effect of insurance becomes more pronounced when damages for serious injury are being assessed.

39 Whether the rules of tort themselves have been changed to reflect insurance is more difficult to establish. On the one hand, it is certainly true that the foundations of tort remain largely unchanged. Formally, liability still depends upon proof of fault and, even where rules have been revised more in favour of claimants, it is too easy to suggest that insurance is the cause. On the other hand, some judges have acknowledged that they have concerned themselves with who has the deeper pocket, or who was in the better position to distribute, or absorb, a loss. It is difficult to conclude that loss distribution arguments have influenced only the facts found and not, to some degree, the rules applied. However, substantial change in tort rules has not occurred. Instead it is the overall involvement of insurers with the system which leads us to conclude that insurance has had a major effect. 


\section{Ought Insurance to Have Influence?}

40 Discussion of whether liability rules and the tort system in general have been influenced by insurance must be distinguished from whether rules should be so influenced. As soon as we start discussing law reform, we cannot focus only upon the distributive effects between the class of victims and the class of wrongdoers. Instead we must also take account of the majority of injured people who are presently left completely outside of the tort system. Whether, for all these people, compensation is better paid via tort liability as opposed to first party loss insurance or state welfare payments depends upon the political, moral and economic prisms through which the question is viewed. "Should the state play a greater role in dealing with misfortune?" invites a wide range of responses. The extent that tort system should be seen as only providing corrective and not distributive justice reflects wider political and moral perspectives. ${ }^{96}$

41 Even within a narrower focus, the argument that the reality of insurance and insurability should be taken into account is a very imprecise one. Whose insurability should we focus upon? By what criteria are we to determine who is the "better" or cheaper insurer when both sides will nearly always be able to purchase cover at some price? By concentrating on insurability we may divert attention from deterrence and whether market forces may have a role to play via tort in affecting risk taking behaviour, although the scope for such a possibility has been much exaggerated often because of its very failure to take into account how insurance actually operates. Description of the influence that insurance has had must therefore be distinguished from the prescriptive effect that others might wish it to have. In contrast to the conclusion we reached above that insurance has had a major influence upon the tort system, and has had at least some part to play upon individual decision making, the view here is that it will not be possible to reach any general agreement on the role that it ought to play.

\section{The Influence of Insurance upon Particular Cases and Rules: Analysis Of Specific Areas}

\section{A. Procedure (Question 24)}

42 Insurers are closely consulted and involved in making rules of civil procedure. These rules permeate the tort system and bring it to life. The Civil Procedure Rules 1998, eight pre-action protocols, ${ }^{97}$ and fixed costs agreements ${ }^{98}$ were

96 For a website debate revealing the divisions among tort scholars see the 2003 postings beginning with Harold Luntz at http://www.ucc.ie/law/odg/messages/030723b.htm.

97 http://www.dca.gov.uk/civil/procrules_fin/menus/protocol.htm.

98 These agreements were reached following mediation by the Civil Justice Council between what were described as the two sides of the personal injury litigation industry. The Civil Procedure Rules were subsequently amended to reflect the agreements. 
the result of lengthy negotiation between interested parties, and insurers played a major part. In particular, insurers' attitudes towards conditional fee agreements and their readiness to embark upon satellite litigation to contest the ability of claimants' lawyers to bring claims has had major effects upon use of tort law. For example, because of the fee changes those suffering from industrial disease are now much less likely to obtain representation, and they will find it even more difficult to obtain compensation than they did previously. ${ }^{99}$

43 Although fee arrangements have been sanctioned which clearly take insurance into account, in a number of other respects the formal rules of procedure have ignored insurance. For example, until they were effectively abolished in 1934, juries were used to a greater or lesser extent to determine tort cases, and there was a rule of practice at the Bar that a jury was not to be told about the insurance position. ${ }^{100}$ This rule countered the fear that liability might be imposed too readily if laymen were aware that an individual defendant was insured. Previously it was said to be difficult to get a fair hearing from a jury especially in a motor accident case. ${ }^{101}$ The rule has no part to play today because the judge, sitting alone, will be aware from his own experience that insurers are likely to be party to the great majority of tort cases that come before him. Commenting upon the old rule one judge said:

“...[T]hose days are long past. Everyone knows that all prudent professional men carry insurance, and the availability and cost of insurance must be a relevant factor ...." 102

44 Another example of where the legal system refuses to acknowledge the presence of insurance is embedded in the doctrine of subrogation. Standing in its client's shoes, an insurer has a right to defend the claim or bring an action to recoup monies it is liable to pay out under a policy. This involvement in liti-

99 It is true that there has been a proliferation of disease claims recently, numbers rising almost threefold from 73,000 in 2002 to 213,000 in 2004 according to Compensation Recovery Unit figures. However, this is the result of the special compensation rules that have been devised for miners' respiratory diseases and vibration white finger. Almost 740,000 of such claims have been registered since 1999, and are said to be "the biggest personal injury schemes in British legal history and possibly the world" according to http://www.dti.gov.uk/coalhealth/01.htm. However, the move to conditional fees for other disease claims has made solicitors much more reluctant to pursue them as acknowledged at recent Association of Personal Injuries Lawyers meetings. For the difficulties traditionally faced by those suffering from disease see J. Stapleton, Disease and the Compensation Debate (1986).

${ }^{100}$ Discussed by Lord Denning in Post Office v Norwich Union Fire Insurance Soc Ltd [1967] 2 QB 363 at 375 . If the rule were breached, the jury could be discharged. Askew v Grimmer (1927) 43 TLR 354.

${ }^{101}$ Scrutton LJ in Gowar v Hales [1928] 1 KB 191 at 197.

${ }^{102}$ Lord Griffiths in Smith v Bush [1990] 1 AC 831 at 858. 
gation via subrogation is accomplished by using not the name of the insurer itself, but that of its policyholder alone. As a result the law reports are replete with what are fictitious actions, and students are often left with little indication of the importance of insurance to the civil system. ${ }^{103}$ The press and public are similarly left in ignorance of the insurance background. This cloak of anonymity has only rarely attracted the criticism it merits. ${ }^{104}$

45 Procedural problems can be caused by failing to recognise the role of insurers. For example, it may be necessary to serve documents directly upon the defendant himself. The insurance company may not suffice. ${ }^{105}$ In particular, the Motor Insurers Bureau, which administers the reserve funds for motor vehicle accidents involving uninsured or unidentified drivers, has been able take considerable advantage of the technicalities resulting from the requirements of service. To avoid some of the procedural difficulties, sometimes it has been necessary to create special rules. For example, even though a defendant company is no longer in existence it is now possible for it to be restored to the register of companies solely in order for it to be sued. ${ }^{106}$ Its old insurer cannot then avoid liability for injuries only because it has been dissolved. However, there are difficulties even with this procedure, ${ }^{107}$ and further problems are still caused by the fact that an individual defendant and not an insurer is technically the party to the action.

\section{B. The Duty of Care}

46 The duty concept acts as the gatekeeper of the law of tort insofar as it determines whether novel claims are to proceed further. Taking into account wider policy factors, judges can rule out claims for which there may be no precedent. Policy concerns such as the danger of encouraging a flood of claims and placing an excessive burden upon defendants have been most discussed in relation to the duty concept. However, judges have examined less often the secondary consequence of such a danger - the difficulty of insuring against a very wide liability. Stapleton argues that such a factor is distinct from the morality of imposing an indeterminate liability, and that insurance difficulties alone have been of little importance in decision making. This is because, first-

${ }^{103}$ This includes the ignorant jury who refused to find the named defendant liable because "you sued the wrong people. You should have sued the insurance company." R. Eggleston, Evidence, Proof and Probability (2nd edn. 1983), 73.

${ }^{104}$ R. Hasson, Subrogation in Insurance Law - A Critical Evaluation, [1985] 5 Oxford Journal of Legal Studies, 416.

105 The position in relation to motor insurance has been improved by the European Communities (Rights Against Insurers) Regulations 2002 (SI No 3061) made pursuant to the Fourth Motor Insurance Directive 2000/26/EC.

${ }^{106}$ Companies Act 1989 s 141

${ }^{107}$ The Law Commission, Third Parties - Rights against Insurers Report No 272 (2001), and Lord Chancellor's Department Consultation Paper (2002) http://www.dca.gov.uk/consult/rro/tparties.htm. 
ly, she believes that, where a duty has been found, insurance has only been used as a superfluous additional argument for doing so; and secondly, where a duty has been denied, insurance tends to be ignored even though it may be clear that the defendant could protect himself against the liability.

47 By contrast, it has been argued that the scope of the duty of care expanded directly in relation to the increasing availability of liability insurance from 1880, and it contracted following insurance fears after $1984 .{ }^{108}$ In response Stapleton states that this causal connection can only be made in a very broad sense for, although there were several major fluctuations in liability over the century, there was no equivalent ebb and flow of insurance to account for them. As an illustration, the case that heralded the judicial retrenchment of the 1980s may actually have ignored the insurance position. ${ }^{109}$ This is because the decision severely curtailed liability for causing economic loss, even though it was probable that liability insurance was actually available to cover that loss, or would have been made available if required. ${ }^{110}$ Such insurance exists in other European countries. ${ }^{111}$

48 However, there are cases where insurance has been specifically taken into account. Distribution of loss arguments have been considered particularly relevant where economic loss has been claimed. ${ }^{112}$ In one such case, when considering the general principles to be applied to determine whether a duty of care existed, a judge discussed at length how his decision might be affected by broad views of the economic consequences. ${ }^{113}$ Two specific illustrations of the effect of insurance in a particular case can be given. In the first, a classification surveyor, employed by shipowners, was held to owe no duty of care to those having an interest in the cargo. ${ }^{114}$ In part this was because the court considered their irrecoverable loss was "readily insurable." The second case concerned the liability of a surveyor of property engaged by a mortgagor. He was held liable for his survey to the purchaser of the property who, although not directly commissioning the report, had relied upon it. In preventing the surveyor from disclaiming a duty of care, one judge said that the risk of the surveyor's negligence would be distributed among all house purchasers through an increase in his fees to cover insurance, rather than allowing the whole of the risk to fall upon the one unfortunate purchaser. ${ }^{115}$ These distributional consequences can be hard to assess, and reveal the wide scope for potential

${ }^{108}$ Davies, [1989] 9 Legal Studies, 67.

${ }^{109}$ Murphy v Brentwood DC [1991] 1 AC 378.

${ }^{110}$ Clarke (supra fn. 39), at 277 and 286.

${ }^{111}$ Ibid. Contrast the generally limited provision in European countries described in W. Van Boom et al., Pure Economic Loss (2004), especially at 200.

${ }^{112}$ See cases cited in S. Deakin/A. Johnson/B. Markesinis, Tort Law (5th edn. 2003), 144 et seq.

${ }^{113}$ Hoffmann J in Morgan Crucible Co v Hill Samuel [1991] Ch 295 at 302.

${ }^{114}$ Marc Rich \& Co v Bishop Rock Marine Co Ltd [1996] AC 211 at 241.

${ }^{115}$ Lord Griffiths in Smith v Bush [1990] 1 AC 831 at 859. 
discussion. Fearful of this, and in order to limit speculation, other judges have asked for clear evidence to be presented on matters such as uninsurability. ${ }^{116}$

49 Conflicting judicial views about the relevance of insurance can be illustrated by reference to two recent cases involving injuries suffered when taking part in sport. In the first, insurance was thought relevant to whether a rugby referee owed a duty of care to the players in the game over which he had control. The court accepted that its decision was affected not only by the availability of liability insurance, but also by the countervailing consideration of the ability of the players to take out their own accident insurance. ${ }^{117}$ A duty of care was found. By contrast, in the second case, although again a duty was found, insurance was deemed irrelevant. A duty of care towards a boxer was imposed on the non-profit making Board that governed boxing, and its insurance and financial difficulties that might result were ignored. ${ }^{118}$

50 Where, as in most cases, insurance is not discussed, a few tort commentators still speculate whether it might help to explain a court decision. For example, it has been held that an ambulance service owes a duty of care to those it has been called to attend. ${ }^{119}$ However, the fire service owes no such duty in responding to its emergency calls. ${ }^{120}$ One textbook comments:

"If there is to be a difference between the cases, it seems better to realise that it lies in the fact that the fire service is primarily concerned with saving property and that imposing liability would tend to enure for the benefit of subrogated fire insurers who have taken a premium to cover the risk ...."121

51 By contrast, the person who suffered brain damage as a result of the failure of the ambulance to arrive was unlikely to carry first party insurance against such an injury. It is impossible to disprove the view that insurance may have had an effect upon these decisions, but it can be hazardous to make other than a speculative connection as the above textbook writer did. Such connections are not far-fetched; but in the individual case they remain unproven.

${ }^{116}$ Perrett $v$ Collins [1998] 2 L1 Rep 255 at 277, and the dissent of Lord Lloyd in Marc Rich \& Co v Bishop Rock Marine Co Ltd [1996] AC 211.

${ }^{117}$ Vowles v Evans [2003] 1 WLR 1607, Van Oppen v Clerk to the Bedford Charity Trustees [1990] 1 WLR 235.

118 Watson v British Boxing Board of Control [2001] QB 1134 at 1163.

${ }^{119}$ Kent v Griffiths [2001] QB 36.

${ }^{120}$ Capital and Counties plc v Hampshire County Council [1997] QB 1004.

${ }^{121}$ W.V.H. Rogers, Winfield \& Jolowicz on Tort (16th edn. 2002), 143. This echoes the view of Lord Hoffmann in Stovin v Wise [1996] AC 923 at 954. 


\section{Fault, Strict Liability and the Standard of Care (Question 11)}

52 The standard of care has been said to be affected by insurance because judges have a wide discretion to interpret what may be expected of the reasonable man. They can demand a very high level of care and, in effect, impose strict liability through the fiction of fault. The standard of care can be made more objective by being divorced from the particular circumstances, and excuses, of the defendant. We have already cited the example of the learner driver held to the standard of care of a fully qualified driver, and the reasonable man at times has been said to require "agility of an acrobat and the foresight of a Hebrew prophet."

53 Although it is tempting to assert that it is insurance that accounts for these high standards, other explanations are possible. For example, one judge recently acknowledged that the great care required of motorists merely reflected the fact that the car is a very dangerous weapon and the pedestrian very vulnerable. ${ }^{122}$ Moreover, it is clear that the scope of liability does not correspond to the extent of potential protection provided by insurance. Firstly, as a modern example we might note that the standard of care required of doctors has not been stretched to exceptional levels in spite of the availability of insurance. Secondly, it must be remembered that in the nineteenth century defendants were held liable for extensive damage long before liability insurance became readily available from around $1880 .{ }^{123}$ The formal rules of tort then offered considerable scope for the imposition of strict liability long before there were ideas that this might be economically efficient or that losses might be channelled into deeper pockets. Although the liability insurance market became well established in the early part of the twentieth century, it was the fault principle, rather than strict liability, that came to dominate the formal law. The loss spreading and insurance rationales of strict liability were largely abandoned by the common law after a landmark case in 1946, which saw the triumph of fault. ${ }^{124}$ Thereafter strict liability could usually only be found where courts labelled as fault those acts which were far from being so in reality. Although statute has imposed some strict liability, it is limited and, apart from in work accident cases, and for some aspects of economic loss, ${ }^{125}$ it has had little practical effect. Insurance therefore has had very limited effect in encouraging the development of rules of strict liability.

122 Russell v Smith [2003] EWHC 2060 and Eagle v Chambers [2004] RTR 9.

${ }^{123}$ Its roots can be traced back to the early nineteenth century and marine insurance. However, the major stimulus was provided later in the century as a result of engineering risks and employers' liability. Ch. Parsons, From Accident to Liability - A Brief History of Liability Insurance, [2002] 17 (2) Insurance Research \& Practice, 23, W.A. Dinsdale, A History of Accident Insurance in Great Britain (1954).

${ }^{124}$ Read v Lyons \& Co Ltd [1947] AC 146.

${ }^{125}$ K.M. Stanton, The Modern Law of Tort (1994), chap. 17. 
54 The fault principle continues to thrive in spite of the growth of insurance. A claim will fail unless fault is proven no matter how much insurance the defendant carries. For example, no damages are payable as a result of an accident in which the driver dies of a heart attack before the collision occurs, or where the driver is suddenly affected by an illness of which he had no prior knowledge. ${ }^{126}$ Not only will there be no liability in tort, but there can be no claim on any reserve fund. Strict liability has been imposed for many work accidents where statute prescribes the standard of care required. However, it is still possible for a defendant to avoid liability by arguing that the statute requires proof of fault, or that its breach was not the cause of the injury to the claimant. A couple of very recent cases illustrate this. The failure to provide a safe working platform was held not to be the cause of injury when a claimant fell from an unsafe platform as a result of it being deliberately toppled in anger by a workmate. ${ }^{127}$ Similarly, even though an employer supplied safety boots that contained a hole and caused the claimant to suffer frostbite, there was no liability because this was not a risk against which the steel-capped boots were intended to guard. ${ }^{128}$ Although insurance undoubtedly influenced the imposition of strict liability upon employers in the first place, it is but part of a complex mixture of factors determining whether damages will be paid. In many cases the morality behind the fault principle, or the notion of responsibility, has sufficient strength to override the fact that the defendant is insured. Insurance has brought about no sea change in the formal basis of liability and its influence is partial at best.

\section{Causation}

55 Although drawing a line to liability based on causation is open to wide ranging influences, cases that specifically refer to insurance are few indeed. Even in a major recent case dealing with injury by asbestos where the amounts of compensation at stake were exceptional and policy issues to the fore, insurance was not mentioned. ${ }^{129}$ This has not prevented commentators from suggesting that the hidden hand of insurance might explain the very generous view of causation taken in a number of personal injury cases where liability has been imposed for freak accidents or bizarre results. ${ }^{130}$ However, again the influence of insurance is inconsistent for it is possible to point to cases that have adopted a less generous approach. Some claimants have been denied de-

${ }^{126}$ Mansfield v Weetabix [1998] 1 WLR 1263

${ }^{127}$ Horton v Taplin Contracts [2003] PIQR P12.

${ }^{128}$ Fytche $v$ Wincanton Logistics [2004] UKHL 31.

${ }^{129}$ Fairchild v Glenhaven Funeral Services [2003] AC 32 noted by K. Oliphant in: H. Koziol/B.C. Steininger (eds.), European Tort Law 2002 (2003), 144. J. Morgan, Lost Causes in the House of Lords, [2003] 66 Modern Law Review, 227 at 282 notes that the sums involved in this case were "staggeringly large" and cites a press release from the construction union UCATT headlined "insurance companies hit for $£ 6$ - $£ 8$ billion."

${ }^{130}$ Cane (supra fn. 2), 106. 
spite their need of compensation, and even though the defendant was not only at fault but also insured.

56 Insurance has been said to be a factor in certain cases where the causation rules have been applied in a restricted way to provide for only a very limited liability in relation to property damage. ${ }^{131}$ Claimants are much more likely to carry first party insurance for such damage than they are to be insured against personal injury. Lord Hoffmann recently stated:

"Property insurance is relatively cheap and accessible; in my opinion people should be encouraged to insure their own property rather than seek to transfer the risk to others by means of litigation, with the heavy transactional costs which that involves." 132

57 However, in the same case Lord Hobhouse denied that insurance should affect principles of liability:

"The argument that insurance makes the rule unnecessary is no more valid than saying that, because some people can afford to and sensibly do take out comprehensive car insurance, no driver should be civilly liable for his negligent driving."

58 In an earlier case, Lord Denning, following the Hoffmann reasoning, explicitly argued that no liability should be imposed, and there should be a break in the chain of causation, partly because the claimant could have relied on first party insurance against property damage. ${ }^{133}$ In fact, the judge may have been wrong in this for the property had been empty for some time and, as a result, no insurance may have been in force. ${ }^{134}$ The case may illustrate that when courts try to take wider factors into account they may find the position more complex than at first appears. They may lack the technical evidence required, and their speculation about the insurance position may prove quite wrong. ${ }^{135}$

${ }^{131}$ For example, the limited liability imposed for damage caused by fire in the USA. J.G. Fleming, An Introduction to the Law of Torts (2nd edn. 1985), 15, W. L. Prosser, Law of Torts (4th edn. 1971), 553.

132 Transco v Stockport Metropolitan Council [2003] 3 WLR 1467. Similarly Lord Diplock in Photo Productions v Securicor Ltd [1980] AC 827 at 85, and contrast Lord Denning in the lower court who considered that a plaintiff's loss insurance could be cancelled out by a defendant's liability insurance [1978] 1 WLR 856 at 866

${ }^{133}$ Lamb v Camden LBC [1981] QB 625.

${ }^{134}$ B. Lee/R. Merkin, Human Action as Novus Actus Interveniens, [1981] New Law Journal, 965.

${ }^{135}$ Clarke (supra fn. 39), 292 notes that information on insurance may be hard to obtain, and argues that the reasons for putting a ceiling on the liability of carriers, for example, do not bear close scrutiny. 


\section{E. Defences}

59 It is possible to view certain cases in which courts have refused to apply defences which would deprive the claimant of all or part of the damages as being influenced by the insurance position. For example, the ability to pay is said to account for cases in which the tiredness of a worker which helps to cause his own injury is held not to constitute contributory negligence, and his damages are not then reduced. By contrast, the tiredness which results in injury to another worker, and for which the employer could be vicariously liable, is held to be negligence. (Question 11)

60 However, courts never refer to insurance specifically in this context, and the argument again depends on cases being determined by hidden factors, and accepting that its effect on the law, at best, is partial. On the one hand, insurance may have influenced both judges and Parliament in that they have restricted the scope of the defence of consent in areas where insurance is compulsory. For example, in motor accidents a statute prevents a passenger's claim from being defeated by any express or implied agreement he may have made with the driver. ${ }^{136}$ This means that his claim cannot be defeated by a notice in the vehicle disclaiming any liability. Similarly for work accidents, judges have determined that where an employer is in breach of his statutory duty the claim against him cannot be avoided by pleading that the worker consented to the state of affairs. On the other hand, however, it must be emphasised that contributory negligence continues to be applied frequently in personal injury claims, reducing damages in about a quarter of all cases that are settled. ${ }^{137}$ In a recent case damages were reduced by as much as 60 per cent in spite of the defendant being in breach of statutory duty. ${ }^{138}$ Furthermore, even the defence of consent survives in a handful of cases to defeat a claim from those who are extremely foolhardy, such as the passenger who chose to take a joyride in a plane, rather than a car, with a pilot with whom he had consumed a great deal of alcohol. ${ }^{139}$ The morality of the fault principle is hard to eradicate in such a case, no matter what the level of insurance.

61 In one case, although consent failed as a defence involving a claim for occupier's liability, warning notices displayed at the behest of the liability insurer were held to be effective to deny a duty of care to a spectator at a motor race. ${ }^{140}$ The case is especially notable for the dissent of Lord Denning who, because of the insurance factor, would have allowed damages. He thought that the insurer's warning notices should have been ineffective because insurers should not be allowed to take the premiums and yet avoid the liability. How-

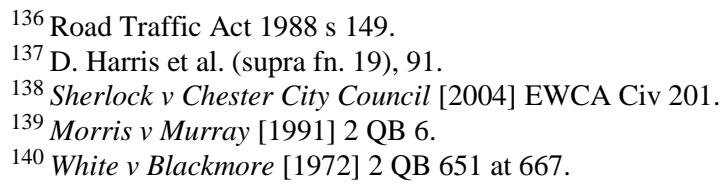


ever, the other judges did not share his analysis. A statute was later passed which today may enable such a claim to succeed. It prevents an occupier of business premises from excluding liability for death or personal injury to visitors. However, an exclusion relating to property damage is allowed if it is reasonable. One of the factors affecting this, and specified in the statute, is the availability of insurance. ${ }^{141}$ (Question 22)

\section{F. Vicarious Liability}

62 The principle of vicarious liability holds an employer strictly liable for the torts of an employee acting in the course of his employment. This has been justified on the basis that it enables losses to be borne by those with deeper pockets, and that employers are better placed to make insurance provision. ${ }^{142}$ Although these justifications may help account for some aspects of the liability, again they will not suffice to justify the full scope of the rule. For example, there is usually no vicarious liability for the acts of independent contractors even though the needs of the claimant and the ability of the employer to insure may be the same. Nor is there liability if the employee acts outside the course of his employment. Even where recent decisions appear to impose a stricter liability, judges do not refer to insurance as a factor. ${ }^{143}$ It cannot be asserted that there is a direct correlation between the availability of insurance and the imposition of vicarious liability when the basic rule is subject to such major exceptions for which insurance cannot account. Stapleton stresses this point, and argues that the wide approval of the vicarious liability limits undermines the relevance of insurability as a factor in tort law. ${ }^{144}$ However, although it cannot be viewed as a sole factor, insurance cannot be discounted as an influence upon the expansion in liability.

63 In a vicarious liability case in 1957 a court notably refused to take insurance into account and this led to measures being taken to avoid its result. ${ }^{145}$ The insurer of the employer found vicariously liable successfully reclaimed the damages for which it was responsible from the negligent employee who had caused the accident. Although the action was brought via subrogation in the name of the employer, it was pursued against the employer's wishes. Employers generally were opposed to such recovery by insurers. Together with trade unions, they considered that it would be bad for industrial relations if responsibility for shop-floor accidents were to be transferred to uninsured employees

${ }^{141}$ Unfair Contract Terms Act 1977 s 11 (4).

142 P.S. Atiyah, Vicarious Liability in the Law of Torts (1967), $22-28$.

${ }^{143}$ For example, liability has recently been imposed for sexual assaults carried out by a warden on boys at a boarding school in Lister v Hesley Hall [2001] 2 WLR 1311, and for the deliberate stabbing of the claimant by a nightclub steward away from his place of employment in Mattis v Pollock [2003] 1 WLR 2158. Glofcheski, A Frolic in the Law of Tort: Expanding the Scope of Employers' Liability, [2004] 12 Tort Law Review, 18.

144 (Supra fn. 92), 828

${ }^{145}$ Lister v Romford Ice Co [1957] AC 555. 
in this way. As a result, after the case they came to a private agreement with insurers' representatives that subrogation would not be used in this way again. The full effects of the fault system were therefore abandoned in practice. Although this was achieved without judicial assistance, the result is that it is insurers, and never employees, who pay the tort bill.

\section{G. Assessment of Damages (Questions 18 to 20)}

64 Contrary to the impression that may be gained from a tort textbook, it is quantum rather than liability that is the more important issue for a practitioner. Insurers are far more likely to contest the amount of damages claimed rather than whether there has been a breach of duty. Arguments that the defendant did not cause the injury or owed no duty of care are rare indeed. Too little attention has been paid by academics to the damages award. It should be a focus of concern not only when the efficacy of the tort system as a whole is being discussed, but also when the justice of any tort rule is being scrutinised. The debate about the influence of insurance upon tort similarly reflects too little concern about the damages award.

65 It is clear that, at least in cases of serious personal injury, "the size of damages awards ... is explicable only on the basis that judges are influenced by the widespread presence of insurance." 146 This is a major point. The extraordinarily high level of damages all paid in one lump sum is the feature of the tort system that distinguishes it from welfare and other compensation systems. Liability insurance enables tort to espouse its distinctive rhetoric: it purports to make an assessment of loss that is not only tailored to the individual claimant, but sufficient to restore the position before injury took place. These claims are greatly overstated, ${ }^{147}$ and yet form much of the reason for tort's existence. Without a mechanism to distribute the cost of imposing liability, it would rarely be worth assessing damages in the way we do at present in serious injury claims. Without insurance it is doubtful whether the tort system would survive at all. Insurance in this sense provides the lifeblood of tort.

66 In recent years major changes have been made to the assessment of damages, and many of these are predicated upon payment being made either by insurers, or other large self-insured bodies. The assessment of damages has become ever more precise. Actuarial and forensic accountancy evidence has become commonplace. Such matters as the discount rate for early receipt of damages,

${ }^{146}$ P. Cane (supra fn. 2), 204. Similarly Lord Denning in Morris v Ford Motor Co [1973] 1 QB 792, 798.

${ }^{147}$ The system fails to achieve its high ideals and, within its own terms, often undercompensates the more seriously injured claimants. R. Lewis et al., Court Awards of Damages for Loss of Future Earnings: An Empirical Study and an Alternative Method of Calculation, [2002] 29 Journal of Law \& Society, 406 and [2002] J Personal Injury Law 151, and Loss of Earnings Following Personal Injury: Do the Courts Adequately Compensate Injured Parties? (2003) 113 Economic J 568. 
the interest rate on delayed payment, and the inflation factor enabling past awards to be compared with those of the present day have all been more closely linked to the wider financial world. In a few serious injury cases lump sum payment has been replaced in part by a periodic pension, and the courts now have the power to order that damages take this form even if the parties object. ${ }^{148}$ It is impossible to conceive of such developments - involving continuing lifetime obligations to make increasing payments - if it were not for the fact that individuals almost never pay tort damages themselves. The argument here is that it is not easy to divorce these changing rules on assessment and payment of damages from the fact that it is insurers who run the tort system.

67 A previous ECTIL report examined in detail the extent that damages take account of the actual receipt of insurance monies, whether deriving from private or public sources. ${ }^{149}$ That report noted that there is a trend in the UK towards preventing claimants obtaining double compensation by reducing damages to take account of these collateral benefits. Thus a series of cases in recent years have deducted various types of social security benefit. In one of these cases a judge recognised the reality that damages are met from insurance premiums, and to allow a claimant to recover twice, at the expense of insurers, could not be justified. ${ }^{150}$ Following the institution of statutory scheme in 1990, social security benefits are now recovered by the state from damages awards. Insurers are required to deduct benefits from any tort compensation they pay, and reimburse the state. However, no account is taken of any private insurance from which the claimant benefits ${ }^{151}$ unless it relates to a policy paid for by his employer alone. ${ }^{152}$ It is therefore still common for over-compensation to take place. For example, in two thirds of the cases where negligence causes death, the estate benefits from receipt of life insurance monies in addition to tort damages. ${ }^{153}$ Private insurance is therefore usually ignored by the tort system, whereas public insurance is now almost always deducted from damages, and this has reduced the incentive to sue in tort.

68 Apart from this example, the extent that insurance influences damages in particular cases, as opposed to the system in general, is much less clear. In the USA individual damages awards have clearly been affected by insurance policy limits. There is evidence that lawyers do not pursue claims beyond these

${ }^{148}$ The Courts Act 2003 s 100. R. Lewis, Structured Settlements: The Law and Practice (1993).

${ }^{149}$ U. Magnus (ed.), The Impact of Social Security Law on Tort Law (2003).

${ }^{150}$ Lord Bridge in Hodgson v Trapp [1989] 1 AC 807.

${ }^{151}$ Bradburn v Great Western Railway Co (1874) LR 10 Exch 1, and R. Lewis, Deducting Benefits from Damages for Personal Injury (1999), chap. 8.

152 Pirelli General Plc v Gaca [2004] EWCA Civ 373.

${ }^{153}$ The Law Commission, Personal Injury Compensation: How Much is Enough? (1994), Report no. 225 para. 13.8 . 
limits in order to obtain "blood money" from defendants personally. ${ }^{154} \mathrm{How}$ ever, in the UK the policy limits for a claim are almost never relevant, and therefore it is less easy to see the precise effect of insurance cover. As in other areas, judges have expressed different views concerning the relevance of insurance and this results in much uncertainty. Their diversity of approach can be illustrated by three leading appellate cases. Although they all mention insurance, in only one of them was there any detailed discussion of the wider effects on society of substantially increasing damages, and in the first of them the relevance of insurance was emphatically denied.

69 In this first case damages were sought for the care freely given by a spouse to his loved one following her serious injury. ${ }^{155}$ It was established law that such a claim could be made even though the husband did not charge his wife for the help he gave her. However, the complicating factor was that the wife's injury had been caused by the husband's own negligence. He was thus both tortfeasor and carer. The court held that his wife could not succeed in her claim for the cost of care that he had freely given. A tortfeasor could not be expected to pay twice for the injury by not only giving the care, but then also having to pay for it. The claimant had argued that this ignored the reality that it was the husband's insurer that would pay, not the husband himself. However, the House of Lords strongly rejected the relevance of insurance, and this was later supported by the Law Commission for the "danger otherwise is that decisions as to where liabilities should be imposed will be made on the basis of who happens to be insured."156

70 In the second of the cases, the court again took a conservative line with regard to the relevance of insurance when it substantially increased compensation to allow more precisely for the return on investment of a lump sum award of damages. Actuarial evidence showed that previously claimants had been under-compensated because they had been expected to obtain an unrealistic rate of interest. To pay for the increase in damages the court recognised that insurance premiums would have to rise. "Whether this was something which the country can afford is not a subject on which your Lordships were addressed. So we are not in a position to form any view as to the wider consequences."157 Any change to the rule that the defendant had to pay damages in full could only be made by Parliament "which, unlike the judges, is in a position to balance

${ }^{154}$ T. Baker, Blood Money, New Money and the Moral Economy of Tort Law in Action, [2001] 35 Law \& Social Review, 275.

${ }^{155}$ Hunt $v$ Severs [1994] 2 AC 350.

${ }^{156}$ Law Commission, Damages for Personal Injury; Medical, Nursing and Other Expenses (1999), Report No 262 para. 3.74.

${ }^{157}$ Lord Lloyd in Wells $v$ Wells [1999] 1AC 345 at 373. 
the many social, financial and economic factors which would have to be considered...."158

71 By contrast, in the final case, evidence of the wider consequences of raising damages for non-pecuniary loss was presented to the court, and had considerable effect upon the outcome. ${ }^{159}$ (Question 20) Although involving questions of social policy, the level of damages was not thought a matter for Parliament alone. However, the court drew a distinction between its role in a claim for pecuniary as opposed to non-pecuniary loss: for pecuniary loss, the court was only required to make the correct calculation, and economic consequences were irrelevant; whereas for non-pecuniary loss, the court was concerned with what was fair, just and reasonable, and the impact upon society was then a relevant factor. The court was to avoid setting damages "at a level which would materially affect the cost of living or disturb the current social pattern...." 160 As a result it was important to consider how the insurance industry might be affected by any change. In addition, the consequences for the $\mathrm{Na}$ tional Health Service (NHS) in paying for the effects of clinical negligence had to be considered. Various parties submitted written evidence to the court giving details of the effect on insurance premiums of a change in the way damages are assessed. They also dealt with the consequences for the NHS if its resources were to be depleted by increasing awards of compensation. Although these matters were discussed in general terms in the judgement itself, there was no examination of the detailed calculations. Nevertheless a decision was reached which was broadly favourable to defendants: although damages for pain and suffering were increased by up to a third in the most serious injury cases, no increase was made for the mass of claims involving minor injury. Compared to the Law Commission's proposal for a substantial increase in damages for a much broader range of cases, this change caused insurers little difficulty. The Commission had attached much less importance than the court to the wider consequences for society and had not considered cost to be relevant. Although the court tried to confine these wider ranging arguments to non-pecuniary loss cases, it was directly influenced by the impact of any change in assessment upon insurance.

72 Wider ranging factors which might influence damages for personal injury were also discussed in a case which considered whether such awards must be

${ }^{158}$ Lord Hutton ibid at 405. Similarly Lord Scarman in Lim v Camden Area Health Authority [1980] AC 174 at 187 considered the effect of higher awards on insurance premiums and the NHS matters for Parliament.

${ }^{159}$ Heil v Rankin [2001] QB 272 discussed by R. Lewis, Increasing the Price of Pain, [2001] 64 Modern Law Review, 100.

${ }^{160}$ Diplock LJ in Wise v Kaye [1962] 1 QB 638 at 669. Lord Denning feared small insurance companies could be ruined if premiums were increased and he was concerned about their wider effect upon "the body politic" in Fletcher $v$ Autocar and Transporters Ltd [1968] 2 QB 322 at 335, but see Salmon LJ at 363. 
considered as comparitors when damages for defamation are assessed. ${ }^{161}$ In deciding that comparison need not always be made, Lord Hoffmann noted that damages for personal injury, unlike those for defamation, are almost always paid either by insurers or out of public funds and, as he stated elsewhere, "spread across the whole community by an intricate series of economic links." 162 Their exemplary and deterrent effects are minimal or non-existent. The total sums paid out by the personal injury system are very large and have an effect upon the economy as a whole. As a result, he argued, the amounts awarded depend to some extent upon what society can afford to pay the victim. By contrast, these considerations have little part to play when damages for defamation are assessed.

\section{H. Punitive damages}

73 Insurance has had little effect upon the award of punitive damages in the UK. (Question 19) The bases for such an award are extremely limited and in practice they affect areas where private insurance has little role to play, such as claims against government bodies. By far the most important area where insurance is taken out relates to the liability of police authorities. However, the amount of damages awarded against such body, given that it is publicly funded, is unlikely to be affected by whether or not there is insurance as well.

74 In one case an insurer contested whether it had a duty to pay punitive damages under the terms of its standard liability policy. ${ }^{163}$ However, the court held that the wording did cover punitive damages, and that there was no rule of public policy to rule out such cover at least in respect of a police authority's vicarious liability. The Law Commission has recommended that punitive damages be extended. ${ }^{164}$ It also considered whether defendants should be allowed to insure against the possibility of such damages being awarded, and concluded that there should be no restriction. However, police authorities have reported that it is now difficult to arrange such cover. ${ }^{165}$

\section{Insurance and Statute}

\section{A. Insurers' Lobbying and Influence upon Legislation}

75 A wide range of legislation going far beyond liability concerns can affect insurers. They formed their own trade association in 1917 partly in order to respond to potential changes in the law. The Association of British Insurers

${ }^{161}$ The Gleaner Co Ltd v Abrahams [2003] 3 WLR 1038 at 1053.

${ }^{162}$ Dimond v Lovell [2000] 2 WLR 1121 at 1133.

${ }^{163}$ Lancashire County Council v Municipal Mutual Insurance Ltd [1997] QB 897.

${ }^{164}$ Law Commission, Aggravated, Exemplary and Restitutionary Damage (1997), Report no. 227.

${ }^{165}$ However, insurance is always available via off-shore policies issued from places like Bermuda. T. Baker, Insurance Law and Policy (2003), 526. 
(ABI) has since grown to such an extent that, with one exception, it is now more than twice the size of any other trade association. ${ }^{166}$ With an annual budget of over $£ 20$ million, it has been very effective in putting forward the industry's point of view. The regulatory framework of insurance reflects the success of the ABI in arguing for forms of self-regulation in lieu of statutory controls, and for exemption from general legislation that might otherwise apply. Insurance remains the least regulated of contracts, and its exemption from domestic legislation dealing with unfair contract terms "amazing." 167

76 One forthright example of the ABI pressing its case is where it issued a press release just before an appellate hearing was due to take place. In the release it threatened insurers' withdrawal from a particular market in the event of the court finding liability. ${ }^{168}$ More effective has been its regular lobbying of government ministries. One insurance commentator has even suggested that internationally institutions such as the ABI "see themselves as governing governments." 169 In addition to lobbying ministries, the ABI has ensured that its case is heard in Parliament. Until 1997 one in ten Members of Parliament declared a financial link with the insurance industry, ${ }^{170}$ although this figure has been halved for the current Parliament. ${ }^{171}$

77 The $\mathrm{ABI}$ is organised so as to respond to all government proposals to change the wide areas of law with which it is concerned. In 1998 the government announced that no proposal for regulation which has an impact upon businesses would be considered by ministers without a "regulatory impact assessment" being carried out. Rather than being just another bureaucratic requirement, the new procedures offer business and industry a major opportunity to influence the policy and legislative process. ${ }^{172}$ Parliamentary Bills are now accompanied by impact statements assessing the financial costs and benefits of the measures being proposed. In drawing up such statements civil servants are directed to consult widely. Twenty or so bodies are specifically named, one of them being the $\mathrm{ABI} .{ }^{173}$ As a result, it is automatic for the $\mathrm{ABI}$ to be asked to

${ }^{166}$ M. Boleat, Trade Association Strategy and Management (1997), 21.

${ }^{167}$ As described by the former Director-General of Fair Trading, G. Borrie, in: The Development of Consumer Law and Policy - Bold Spirits and Timorous Souls (1984), 110.

168 A. Layard, Insuring Pollution in the UK, [1996] Environmental Liability, 17 at 18.

${ }^{169}$ R.V. Ericson et al., Insurance as Governance (2003), at 151. See also R.V. Ericson/A. Doyle, Uncertain Business: Risk, Insurance and the Limits of Knowledge (2004).

${ }^{170}$ Clarke (supra fn. 39), 281.

${ }^{171}$ The author's examination of the Register of Members' Interests in February 2004 revealed that only eight members of the House of Lords declared an insurance interest, one being membership of Lloyds. Only fifteen Members of Parliament declared any connection with insurance companies, although a further ten recorded that they were current members of Lloyds and nine others that they were former members.

172 C. Miller, Political Lobbying (2000), 251.

${ }^{173}$ Cabinet Office, Better Policy Making: A Guide to Regulatory Impact Assessment (2003) http://www.cabinet-office.gov.uk/regulation/scrutiny/ria-guidance.pdf. 
estimate the effect of proposed reforms on insurance premiums. Insurability is therefore now a relevant consideration whenever statutory changes affecting tort are being considered. (Question 5) Impact statements have given insurers a more formal and public opportunity to make representations to government, but it is doubtful whether this has given them much more influence than they had previously. This is because their most effective representations continue to be exercised in private, behind closed doors. ${ }^{174}$

78 One illustration of the effectiveness of such private lobbying is the overturning of a Law Commission recommendation that a particular financial formula be used to set the discount rate in assessing damages. (This rate makes allowance for the investment return upon lump sum damages). In the Damages Act 1996 the Commission's recommendation was replaced by a power given to the Lord Chancellor to change the rate as he saw fit. However, this discretionary power was not exercised for some time, and when a rate was eventually set it was less favourable to claimants than if the Commission's formula had been used. The Opposition spokesman in Parliament noted that the change in the Act was "mightily convenient to the insurance industry" and commented that it was the result of "whispering in appropriate ears." 175 The effectiveness of this private lobbying is difficult to monitor, and has received only limited attention from public lawyers. It reveals "a hidden dimension of the law which many lawyers may prefer to leave decently covered." 176

\section{B. The Influence of Insurance upon Particular Tort Statutes}

79 Statute has been affected not only by the lobbying of insurers on specific matters, but also, in a more general way, by developments in insurance provision. As with caselaw, it can be argued that new legislative rules reflect the tort system's ability to distribute the cost of injury via insurance. The influence has been said to be clearer in relation to statute than caselaw. ${ }^{177}$ However, others might argue that among the relatively few statutes that deal directly with tort, there are examples of legislation, such as that dealing with occupiers liability, which take little notice of the incidence or potential scope of liability insurance.

80 By contrast, certain legislative measures can only be explained by reference to the insurance background. For example, one statute exempts from liability any mother causing injury to her unborn child. However, it is subject to an exception where the injury results from the mother's negligent driving of a motor vehicle, and the mother then can be sued. ${ }^{178}$ Although this Act generally re-

${ }^{174}$ See Boleat (supra fn. 166), chap. 7-8 and especially 61-64.

${ }^{175}$ R. Lewis, Lobbying and the Damages Act 1996: 'Whispering in Appropriate Ears', [1997] 60 Modern Law Review, 230.

${ }^{176}$ C. Harlow/R. Rawlings, Pressure through Law (1992), 60.

177 Clarke (supra fn. 39), 283.

${ }^{178}$ Congenital Disabilities (Civil Liability) Act 1976. 
flects a desire to prevent disputes among family members, its effect is limited in that one area where insurance against liability is compulsory. Similarly the reform which abolished the rule which prevented actions between husbands and wives has been explained by the need to access insurance funds where a road accident had occurred. ${ }^{179}$ (Question 21) Under that legislation a stay of action may be ordered by a court where no substantial benefit would accrue to either husband or wife, the intention being that this power would be exercised in situations where no insurance existed. The spread of insurance provision is also said to account for a series of statutes which have expanded the scope of liability such as those enabling actions to be brought against the estates of deceased tortfeasors, ${ }^{180}$ dissolved companies, ${ }^{181}$ or by claimants who are partly at fault themselves. ${ }^{182}$ One statute familiar to all tort students explicitly takes insurance into account for it declares that, in determining whether a notice is sufficient to exclude liability, the court must have regard to the availability of insurance. ${ }^{183}$

\section{Liability Insurance Crises (Question 7)}

81 On several occasions in the past liability insurance has been said to be in crisis. Symptoms have included the failure of liability companies, or their withdrawal from particular markets. More commonly it has been a very steep rise in the cost of insurance that has signified that all is not well. If insurers increase premiums to a very high level more motorists and employers will fail to comply with their duty to insure. A rise in premiums may also deter activities that the community at large needs, or result in costs which the community can ill afford. However, the extent to which these crises have been precipitated by changes in tort rules themselves is a matter of controversy. Here it will be argued that it has been other factors that have been much more important. Even though the crises have been used to justify sharp increases in premiums, the cost of liability insurance remains very small for the great majority of businesses. For example, the average cost of employers' liability insurance is only 0.25 per cent of the payroll. ${ }^{184}$

${ }^{179}$ Law Reform (Husband and Wife) Act 1962.

${ }^{180}$ Law Reform (Miscellaneous Provisions) Act 1934.

${ }^{181}$ Companies Act 1989 s 141.

${ }^{182}$ Law Reform (Contributory Negligence) Act 1945

${ }^{183}$ Unfair Contract Terms Act 1977 s 11 (4).

${ }^{184}$ Department of Work and Pensions, Review of Employers' Liability Compulsory Insurance: First Stage Report (2003). However, a general building firm would pay one to two per cent, and a firm specialising in high risk construction activities, such as roofing or scaffolding, might be required to pay 15 per cent. Directors' and Officers' liability premiums have risen sixfold since 2001. For a company just within the top one hundred quoted on the stock exchange the increase is from $£ 250,000$ to $£ 1.5$ million, but even this sum is but a small fraction of the firm's turnover. The Times 10 October 2003. 
82 The most recent crisis illustrates that changes in tort law, although giving cause for concern, do not have as much effect upon insurance rates as insurers and others would have us believe. ${ }^{185}$ In 2002, after premiums had fallen by 14 per cent in the previous five years, they rose dramatically. There were increases of 50 per cent for employers liability, 30 to 40 per cent for public liability and 30 to 60 per cent for professional indemnity insurance. The amount which policyholders had to bear themselves before insurance monies could be claimed also rose sharply. These changes resulted in some larger organisations deserting the market and setting up their own captive insurance companies. ${ }^{186}$ Other alleged effects of the rate increase were more controversial. Although there was anecdotal evidence that many firms had been forced to trade illegally, in fact compliance remained high with only 1 in 200 employers in default. ${ }^{187}$ Similarly, although there had been estimates that up to 200,000 small firms were unable to find insurance at all, a report into the crisis from the Office of Fair Trading (OFT) could find little evidence that in fact this was the case. Insurance continued to be available, although sometimes only at a high price. ${ }^{188}$ For example, for the high risks involved in roofing work it was estimated that premiums rose by an average of 161 per cent. Firms most affected were not only those taking high risks, but also smaller firms where the premium rise was likely to account for a higher percentage of their turnover. Independent financial advisers also found that their rates had soared following a wave of scandals that had engulfed the industry. The regulator closed down several operators not having insurance cover. The effect of the rate rise thus differed according to the size and character of the business. However, overall the crisis was not as serious as some had suggested, and the average firm was able to absorb the increased premiums without too much trouble.

83 To what extent had changes in the law of tort contributed to the rise in rates? Previously Cane had attributed the steep increase in the rates set in the 1980s

${ }^{185}$ See F. Furedi, Courting Mistrust: The Hidden Growth of a Culture of Litigation in Britain (1999), and contrast E. Lee et al., Compensation Crazy: Do We Blame and Claim Too Much? (2002) and the Better Regulation Task Force, Better Routes to Redress (2004). The latter, a Government report, concludes that the compensation culture may be a myth, but the perception of it results in real and costly burdens. For an account of exaggerated tort claims by the media in the USA see W. Haltom/M. McCann, Distorting the Law: Politics, Media, and the Litigation Crisis (2004).

${ }^{186}$ In the two years from 2001 the number increased from 245 to 492 . The Times 27 May 2003.

${ }^{187}$ Department of Work and Pensions, Review of Employers' Liability Compulsory Insurance: Second Stage Report (2003), 21. About 112,000 workers were employed where there was no liability insurance.

${ }^{188}$ Office of Fair Trading, An Analysis of Current Problems in the UK Liability Insurance Market (2003). However, there are fears that there will shortly be no cover for asbestos liability. From July 2003 the world's largest reinsurers, Munich Re, Swiss Re and Cologne Re, announced that they would no longer underwrite this liability. If the reinsurance market disappears, companies with workplace asbestos exposure will not be able to obtain cover and many businesses would have to cease trading. The Times 3 June 2003. 
for many professional groups to the dynamics of the insurance industry rather than to changes in tort liability. ${ }^{189}$ A similar conclusion may be reached in relation to the increases made in 2002. According to the OFT report, although changes in the tort system account for part of the increase in the premiums, the main causes lie outside of that system.

84 The most important tort factor is not an increase in the number of claims, but an increase in the level of damages and other costs per claim. For example, for employers' liability, although the number of claims are falling, the cost of each one is rising sharply. ${ }^{190}$ Insurers have suggested that the most important factor causing this rise is not the changing law, but the specialisation of claimants' lawyers and their access to better information on comparable awards. ${ }^{191}$ Claim cost per motor policy rose by an average of almost 10 per cent a year from 1991 to 2000 whereas average earnings rose by only 4.2 per cent. ${ }^{192}$ More tentatively, the OFT report suggests that reforms in civil procedure and the funding of claims may also have encouraged more actions. Finally, and with even more circumspection, increasing liability for "long tail" claims, including asbestos, is mentioned. However, the report notes that insurers have a tendency to exaggerate the effect of changes in tort law as the causes of rises in insurance costs.

85 By contrast, non-tort factors appear to be far more important. These include the uncertainty prevalent in the general insurance climate after the shock of the loss of the World Trade Centre; lower investment returns resulting from the continued decline of the stock market; the cyclical nature of the insurance market; and the structure of the insurance industry which, in the previous five years, has resulted in competition at a level which was unsustainable and which ignored the commercial realities. Overall, therefore, although tort claims costs and liability premiums have increased in recent years, it is diffi-

${ }^{189}$ P. Cane, Liability Rules and the Cost of Professional Insurance, [1989] 14 Geneva Papers on Risk and Insurance, 347

${ }^{190}$ Berman Greenstreet, Workplace Compensation: Costs, Trends and Options for Change (2002). According to the main insurers surveyed, from 1995-98 the rate of claims fell by 20 per cent. The rate of decline has continued. According to the Compensation Recovery Unit work accident claims declined from 97,000 in 2000-1 to 79,000 in 2003-4. Although there was a sharp increase in disease claims, this is explained by the special scheme set up to compensate miners for respiratory disease. Over the four year period claims for all accidents fell from 612,000 to 557,000 a year. This decline in claims has included those for road accidents. Claims frequency fell among motor insurers in both years 1999 and 2000 although it was still 29 per cent higher than in 1992. Association of British Insurers, Third UK Bodily Injury Awards Study (2003), at 24.

${ }^{191}$ Association of British Insurers, Second UK Bodily Injury Awards Study (1999), at 60

${ }^{192}$ Association of British Insurers, Third UK Bodily Injury Awards Study (2003), at 22. 
cult to conclude that they have led to the system being stretched beyond its capacity or that they are the main cause of any "crisis". ${ }^{193}$ (Question 7)

\section{Conclusion}

86 This report has argued that insurance in England and Wales has had a profound effect upon tort and in particular upon the system of personal injury litigation. The influence of insurers upon the everyday practical operation of that system is readily apparent. In addition, they clearly have opportunity and regularly seek to influence the development of legislation affecting liability. Much more difficult to assess is the potential for insurance to affect the outcome of individual claims. Proving that the facts of cases have been moulded to fit the deeper pocket of insurers cannot be done by resort to the law reports alone, but it remains the suspicion of many a practitioner. Although it is easier to assess the influence of insurance upon the rules of tort, rather than the facts found in individual cases, the picture is by no means clear. On the one hand certain rules, such as those discussed in the statute section above, clearly reflect the distributional consequences of insurance. In addition, if the focus changes from establishing liability to assessing damages the general influence may be more apparent. On the other hand, there remain large areas of tort law where the rules appear unaffected by insurance. The conclusion reached earlier in this report was that, at best, the influence of insurance upon the common law rules is only partial. Instead, it is with regard to the system as a whole - whether involving statutory or common law rules, fact finding, or everyday operation - that insurance can be seen as of vital importance. It is the lifeblood of the system.

${ }^{193}$ For an excellent analysis of the instability of liability insurance markets see C. Parsons, Moral Hazard in Liability Insurance, [2003] 28 (3) Geneva Papers on Risk and Insurance. 